\title{
Tetraploid Rangpur lime rootstock increases drought tolerance via enhanced constitutive root abscisic acid production
}

\author{
THIERRY ALLARIO ${ }^{1,2,5}$, JAVIER BRUMOS ${ }^{2,5}$, JOSE M. COLMENERO-FLORES ${ }^{2,4}$, DOMINGO J. IGLESIAS ${ }^{2}$, \\ JOSE A. PINA ${ }^{3}$, LUIS NAVARRO ${ }^{3}$, MANUEL TALON ${ }^{2}$, PATRICK OLLITRAULT ${ }^{1,3}$ \& RAPHAËL MORILLON ${ }^{1,2}$
}

${ }^{1}$ Centre de Coopération Internationale en Recherche Agronomique pour le Développement (CIRAD), UMR Amélioration Génétique et Adaptation des Plantes, ${ }^{2}$ Centro de Genomica and ${ }^{3}$ Centro de Protección Vegetal y Biotecnologia, Instituto Valenciano de Investigaciones Agrarias (IVIA), 46113 Moncada, Valencia, Spain

\begin{abstract}
Whole-genome duplication, or polyploidy, is common in many plant species and often leads to better adaptation to adverse environmental condition. However, little is known about the physiological and molecular determinants underlying adaptation. We examined the drought tolerance in diploid (2x) and autotetraploid (4x) clones of Rangpur lime (Citrus limonia) rootstocks grafted with $2 x$ Valencia Delta sweet orange (Citrus sinensis) scions, named V/2xRL and V/4xRL, respectively. Physiological experiments to study root-shoot communication associated with gene expression studies in roots and leaves were performed. V/4xRL was much more tolerant to water deficit than V/2xRL. Gene expression analysis in leaves and roots showed that more genes related to the response to water stress were differentially expressed in V/2xRL than in V/4xRL. Prior to the stress, when comparing V/4xRL to V/2xRL, V/4xRL leaves had lower stomatal conductance and greater abscisic acid (ABA) content. In roots, $A B A$ content was higher in V/4xRL and was associated to a greater expression of drought responsive genes, including $C s N C E D 1$, a pivotal regulatory gene of ABA biosynthesis. We conclude that tetraploidy modifies the expression of genes in Rangpur lime citrus roots to regulate long-distance ABA signalling and adaptation to stress.
\end{abstract}

Key-words: citrus; ABA; adaptation; polyploidy; water deficit.

\section{INTRODUCTION}

Polyploidy is a frequent occurrence in the plant kingdom (Masterson 1994) and is a major force of plant evolution 3 (Soltis \& Soltis 2009; Chen 2010). Polyploids may be allotetraploids or autotetraploids, resulting either from sexual reproduction via $2 \mathrm{n}$ gametes or somatic chromosome doubling, respectively. Thus, allotetraploids inherit subgenomes from two different parents after interspecific hybridization. In citrus, it is important to note that somatic hybridization is

Correspondence: R. Morillon, Fax: +34963424 106; e-mail: raphael. morillon@cirad.fr

${ }^{4}$ Current address: Instituto de Recursos Naturales y Agrobiología, CSIC, Av. Reina Mercedes 10, 41012 Sevilla, Spain.

${ }^{5}$ These authors contributed equally to the paper.

(C) 2012 Blackwell Publishing Ltd a major source of allotetraploids (Dambier et al. 2011; Grosser \& Gmitter 2011). Autotetraploids, such as most tetraploid citrus genotypes, arise from somatic chromosome doubling and from intraspecific hybridization or selffertilization through $2 \mathrm{n}$ gametes. The subgenomes of these autotetraploids are considered to be identical (Aleza et al. 2011).

Numerous studies focusing on the genetic and epigenetic changes associated with polyploidization have been carried out on newly created allopolyploid materials (Lukens et al. 2006; Rapp, Udall \& Wendel 2009). Ni et al. (2009) proposed that hybrids and allopolyploids have improved control of circadian-mediated physiological and metabolic pathways, and that such changes increase growth vigour and biomass. Those changes in gene expression are potentially advantageous in allopolyploids because an increase in heterozygosity may be at the origin of subfunctionalization (Adams et al. 2003). In allotetraploids, changes in gene expression are thought to be the result of genome hybridization rather than changes in genome ploidy (Auger, Peters \& Birchler 2005; Chen 2010). On the other hand, few studies have sought to identify changes in the genome expression pattern of autotetraploids (Stupar et al. 2007; Riddle et al. 2010; Yu et al. 2010). In contrast to allotetraploids, alteration in the expression of any allele in autopolyploids may lead to a change in phenotype, because no potential complementation or advantageous subfunctionalization could occur. Interestingly, investigations of autopolyploid series in potato, maize and citrus showed that gene expression changes were very limited among plants in the series (Stupar et al. 2007; Riddle et al. 2010; Allario et al. 2011; Li et al. 2012). These results suggest that large phenotypic differences probably correlate with subtle changes in gene expression, rather than with extensive transcription reformatting. Recent work in autotetraploid Arabidopsis thaliana showed that the alteration in transcriptome response does not depend on the chromosome number per se but on the origin of the chromosome (Yu et al.2010). Studies of genome expression in polyploid plants subjected to stress showed that genes duplicated by polyploidy in ancestral polyploids are preserved in their genomes because their expression has been partitioned in response to environmental stress (Liu \& Adams 2007). Ramsey (2011) recently inves- 4 tigated the adaptation of polyploid populations to novel environments and analysed the evolutionary consequences

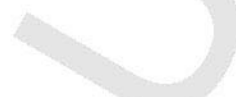


pce_12021

2 T. Allario et al.

of exposure to these environments. He observed that hexaploid wild yarrow (Achillea borealis) and, to a lesser extent, the neo-hexaploid had a fitness advantage over the tetraploids. He concluded that not only polyploidization per se, but also genetic evolution after the polyploidization event, confers improved adaptation to the environment.

Grafting provides an opportunity to investigate the effect of polyploidy on roots versus polyploidy in the entire plant, and there has been continuous strong interest in citrus tetraploid rootstocks in the past decades (Barrett \& Hutchinson 1982; Grosser \& Chandler 2003; Aleza et al. 2011). Tetraploid citrus have lower rates of whole plant transpiration, which is associated with lower growth rates, than their respective $2 \mathrm{x}$ parents (Syvertsen, Lee \& Grosser 2000; Allario et al. 2011). The recent work we performed demonstrated that the use of $4 \mathrm{x}$ rootstocks dramatically changes both tree physiology and fruit yield, without promoting large changes in fruit quality criteria (Hussain et al.2012). Furthermore, based on seedling growth and chloride accumulation in leaves exposed to salinity stress, $4 \mathrm{x}$ citrus seedlings were shown to be more stress tolerant than their respective $2 \mathrm{x}$ parents (Saleh et al. 2008).

In this study, we investigated the water deficit tolerance of $2 \mathrm{x}$ and $4 \mathrm{x}$ clones of Rangpur lime (Citrus limonia) rootstocks grafted with 2x Valencia Delta sweet orange (Citrus sinensis) scions. The use of a $2 \mathrm{x}$ variety allowed us to work with a scion that did not present any phenotypic differences, such as the ones observed between leaves of $2 \mathrm{x}$ and $4 \mathrm{x}$ citrus seedlings (Allario et al. 2011). It has been possible to determine whether the roots of $4 \mathrm{x}$ genotypes are involved in the adaptation to drought by monitoring a specific physiological aspect, such as a change in abscisic acid (ABA) signalling. Finally, the rootstock/variety associations on which we report correspond to combinations that are commonly planted in orchards, underlining the economic importance of this research.

\section{MATERIALS AND METHODS}

\section{Plant material}

Seeds from diploid (2x) (IVIA-334) and autotetraploid (4x) (IVIA-516) of Rangpur lime (C. limonia, Osbeck) were collected from trees of the IVIA germplasm collection in Spain. Originally, the spontaneous autotetraploid genotype (4x) was selected at IVIA among a population of seedlings from the diploid plants. Seeds were planted in substrate (sand, turf and peat, 1:1:1) in a greenhouse for 4 months. The ploidy status of $2 \mathrm{x}$ and $4 \mathrm{x}$ seedlings was checked and confirmed by flow cytometry (Partec I) according to Froelicher et al. (2007). The genetic composition of $4 \mathrm{x}$ seedlings compared with $2 \mathrm{x}$ was analysed using 10 simple sequence repeats (SSRs) according to Allario et al. (2011).

Thirty $2 \mathrm{x}$ and $4 \mathrm{x}$ 1-year-old seedlings were grafted with 2x Valencia Delta sweet orange (C. sinensis, IVIA 363).

5 T-budding was performed $20 \mathrm{~cm}$ above the ground. Trees were grown in the greenhouse for 2 years with day/night temperatures of $20-35{ }^{\circ} \mathrm{C} / 18-20^{\circ} \mathrm{C}$, respectively, and relative humidity varying between 40 and $85 \%$. As V/4xRL trees grew slower than V/2xRL, trees were pruned to equalize tree size. Trees were then transplanted in new $4 \mathrm{~L}$ pots containing fresh commercial soil, and regular fertilization was applied according to Allario et al. (2011). Four months after pruning, $24 \mathrm{~V} / 2 \times R L$ and $24 \mathrm{~V} / 4 x R L$ uniform trees presenting therefore a similar number of leaves for $\mathrm{V} / 2 \mathrm{xRL}$ and $\mathrm{V} / 4 \times \mathrm{RL}$ trees were selected to investigate water deficit tolerance.

\section{Water deficit application}

Trees were regularly watered at field capacity for 2 weeks prior to applying the water deficit. Each pot of the first set of trees was enclosed in a plastic bag. Water requirements to maintain control trees at field capacity were estimated. Six $\mathrm{V} / 2 \mathrm{xRL}$ and six V/4xRL were assigned as control trees. The water deficit was applied by ceasing watering of six tree combinations of $\mathrm{V} / 2 \times \mathrm{xL}$ and six $\mathrm{V} / 4 \mathrm{xRL}$ for $24 \mathrm{~d}$ after bagging the pots. For a second set of $12 \mathrm{~V} / 2 \times \mathrm{xL}$ and 12 V/4xRL trees, six trees of each combination were assigned as control trees, and six trees of each combination were subjected to a water deficit applied without bagging the pots by stopping the irrigation for $11 \mathrm{~d}$ in order to induce a faster stress response.

\section{Leaf physiological parameters, ABA content}

Mature leaves were selected and labelled to avoid leaf anatomy changes and significant developmental adaptation along the stress experiment. Leaf relative water content (RWC) was measured in control condition according to Barr \& Weatherly (1962). Leaf stomatal conductance $\left(g_{\mathrm{s}}\right)$ was also 6 monitored using a leaf porometer (SC-1; Decagon Device, 7 Pullman, WA, USA). The quantum yield of photosystem II electron transport $\left(F_{\mathrm{m}} / F_{\mathrm{v}}\right)$, which represents the photosystem II activity, was checked using a leaf fluorometer (Fluorpen FP 100; Photon Systems Instruments, ••, ••) (Percival 2005). 8 Each measurement $\left(g_{\mathrm{s}}\right.$ and $\left.F_{\mathrm{m}} / F_{\mathrm{v}}\right)$ was taken between 0900 and $1100 \mathrm{~h}$ on 3 mature leaves per plant and 6 plants per genotype (18 replicates). Slides for the analysis of stomatal size and the number of stomata per unit of leaf surface area (stomatal density) were prepared according to Morillon \& Chrispeels (2001). Two segments of the same mature leaf were stuck to the same microscope slide. Three different slides from three different leaf trees were done for each tree combination. A total of 60 stomata were measured. Pots were regularly weighed during the experiment to measure the water consumption. Six independent biological root and leaf sample replicates were harvested from each tree combination (from 0900 to $1200 \mathrm{~h}$ of the day) to prevent any potential interference of circadian rhythms. Six independent biological samples were harvested and frozen in liquid nitrogen on the last day of the experiment. Three root and leaf samples, each one corresponding to a mix of two previously harvested samples, were used for ABA assays according to Xiong et al. (2001). ABA concentration was determined using a Phytodetek ABA Immunoassay Kit, $\bullet \bullet, \bullet$.

(c) 2012 Blackwell Publishing Ltd, Plant, Cell and Environment 


\section{RNA extraction and labelling}

For microarray analyses, 4 independent biological replicates per tree combination and condition were randomly selected among leaf samples. Total RNA purification and a quality assessment were performed as previously described by

9 Brumós et al. (2009). Total RNA was retrotranscribed to cDNA and labelled with the Cy3 and Cy5 fluorophores, following the indirect method, as previously described (Forment et al.2005). Dye incorporation and cDNA recovery were determined by ultraviolet (UV) absorption spectrophotometry using the NanoDrop spectrophotometer (NanoDrop Technologies, Thermo Fisher Scientific, $\bullet \bullet$, DE, USA).

\section{Microarray hybridization and analysis}

The Citrus genome-wide cDNA microarray was used, which includes 21081 putative unigenes described by MartinezGodoy et al. (2008). Two independent microarray hybridization experiments with leaves of the $2 x$ Valencia Delta orange alternatively grafted onto $2 \mathrm{x}$ or $4 \mathrm{xRL}$ rootstocks were respectively performed. For each experiment, the Cy-labelled cDNA of control leaves was hybridized with labelled cDNA from water-stressed samples. To avoid Cy3 and CY5 dyerelated artefacts, control and water-stressed cDNA samples were dye swapped and used to hybridize four slides corresponding to different combinations of the four biological replicates obtained from every treatment. The microarray hybridizations were performed according to Allario et al. (2011). Cy5-labelled cDNA from individual samples was mixed with equal amount of Cy3-labelled reference sample (40-60 pmol of each dye) in $55 \mu \mathrm{L}$ hybridization solution containing $3 \mathrm{xSSC}, 0.1 \%$ SDS and $0.1 \mathrm{mg} \mathrm{mL}^{-1}$ salmon sperm DNA. The hybridization mix was denatured at $95^{\circ} \mathrm{C}$ for $60 \mathrm{~s}$ and applied to a microarray slide previously pre-hybridized. Slide pre-hybridization consisted of $60 \mathrm{~min}$ incubation at $50{ }^{\circ} \mathrm{C}$ in $3 \mathrm{xSSC}, 0.1 \%$ SDS and $0.1 \mathrm{mg} \mathrm{mL}^{-1} \mathrm{BSA}$, washing twice with SSC $(0.1 \mathrm{x})$ and once with distilled water, followed by drying through $5 \mathrm{~min}$ centrifugation at $1000 \mathrm{~g}$. The slide was placed in a hybridization chamber (Olympus, Tokyo, Japan) and incubated overnight (14-16 h) in a bath at $50{ }^{\circ} \mathrm{C}$. After hybridization, slides were washed by stepwise incubations in $2 \mathrm{xSSC}+0.1 \%$ SDS buffer at $42^{\circ} \mathrm{C}$ for $5 \mathrm{~min}, 0.1 \mathrm{x}$ $\mathrm{SSC}+0.1 \%$ SDS buffer at $28^{\circ} \mathrm{C}$ for $5 \mathrm{~min}$ (twice), $0.1 \mathrm{xSSC}$ at $28^{\circ} \mathrm{C}$ for $1 \mathrm{~min}$ (five times), and finally in $0.01 \mathrm{xSSC}$ buffer at $28^{\circ} \mathrm{C}$ for some seconds. Drying was achieved by centrifugation at $1000 \mathrm{~g}$ for $5 \mathrm{~min}$.

A GenePix 4000B microarray scanner (Axon Instruments, Inc., Union City, CA, USA) and the GenePix Pro 4.1 acquisition software were used to scan the chips at 5-10 $\mu \mathrm{m}$ resolution. Photomultiplier gains for the two channels were adjusted so that the ratio of total intensities was approximately 1 and the percentage of saturated spots was about $1 \%$. High-resolution tiff images were generated and used for quantification of gene expression data. Spot positions were identified on the colour images and quality flags were assigned to individual spots both automatically and manually. Only spots with background-subtracted foreground intensity (C) 2012 Blackwell Publishing Ltd, Plant, Cell and Environment greater than 2 in at least one channel were used, and only microarrays with optimal hybridization data were preprocessed and normalized for further analyses. Raw data were imported into the R-computing environment for preprocessing, visualization and statistical analysis. To identify probes showing significant differential gene expression between samples, the linear models for microarrays (LIMMA; Smyth 2005) software package was used. Preprocessing and normalization of two-colour microarray data including signal intensity, background correction, uniformity of the expression ratio over the chip surface (within-array normalization), and normality of $M$-value distributions were evaluated according to Smyth and Speed (2003). $M$-value was 10 defined as the logarithm in base- 2 of water deficit versus control expression ratio. Reproducibility between replicates that were assessed indicated that the experimental system provided consistent signals in spots corresponding to the same gene and acceptable low variability between biological replicates (not shown). $P$-values associated to the statistical analysis of differential expression obtained from LIMMA analysis are corrected for multiple comparisons using the $\mathrm{B} \& \mathrm{H}$ false discovery rate (FDR) procedure (Benjamini \& Hochberg 1995; Reiner, Yekutieli \& Benjamini 2003). Differences in gene expression were considered to be significant when the $M$-value was $\geq / 0.7 /$ and the FDR-adjusted $P$-value was smaller than 0.05

\section{Functional analysis}

Gene ontology (GO; Ashburner et al. 2000) term annotation of array features and function-based analysis of microarray results were carried out with Blast2GO (Conesa et al. 2005). The GO terms for each of the three GO main categories (biological process, molecular function and cellular component) were obtained from sequence similarity analysis using the application default annotation parameters. GO annotations were completed by locally running homology searches according to Quevillon et al. (2005) and applying the second layer GO augmentation strategy (Myhre et al. 2006). GO term enrichment analysis of significantly differentially expressed genes was also performed (Bluthgen, Kielbasa \& Herzel 2005). The data discussed in this publication have been deposited in NCBI's Gene Expression Omnibus (GEO; Edgar, Domrachev \& Lash 2002) and are accessible through GEO Series accession number GSE41311.

\section{Real-time RT-PCR}

Genes that were selected from microarray analysis for (q)RT-PCR investigations were searched for among the sequences in the non-redundant databases using the BLASTN and TBLASTX algorithms and in the citrus EST database (CFGP database, Citrus Functional Genomic project, http://bioinfo.ibmcp.upv.es/genomics/cfgpDB/ bioinfo.ibmcp.upv.es). Primers used for quantitative real- 11 time RT-PCR (Table 1) were defined using the software Oligo Explorer (Gene Link_, http://www.genelink.com/tools/ gl-oe.asp) to select primer pairs with the lowest possible 
JOBNAME: No Job Name PAGE: 4 SESS: 9 OUTPUT: Mon Oct 22 18:58:07 2012

/v2503/blackwell/journals/PCE_v0_i0/pce_12021

pce_12021

4 T. Allario et al.

Table 1. Citrus gene accession number and function and primers used by the selected genes to be confirmed by RT-qPCR results of expression obtained through microarray analysis

\begin{tabular}{|c|c|c|c|}
\hline Gene name & Accession No. & Function of the gene or the encoded protein & Primer sequence $\left(5^{\prime}->3^{\prime}\right)$ \\
\hline \multicolumn{4}{|l|}{ Repressed genes } \\
\hline Carbonic anhydrase $(C A)$ & C01015D11 & $\begin{array}{l}\text { Carbonic anhydrases form a family of enzymes that } \\
\text { catalyse the rapid conversion of carbon dioxide to } \\
\text { bicarbonate and protons and favour photosynthesis }\end{array}$ & $\begin{array}{l}\text { F: CACCAGCTCCTATCATCAAC } \\
\text { R: GCAACAGGTTTCAAGTCTTC }\end{array}$ \\
\hline $\begin{array}{l}\text { Chloroplast oxygen-evolving } \\
\text { enhancer protein }(O E E)\end{array}$ & C31604E09 & $\begin{array}{l}\text { Oxygen-evolving enhancer proteins are auxiliary } \\
\text { components of the photosystem II manganese cluster }\end{array}$ & $\begin{array}{l}\text { F: CTCAGGTTCCTTTGTTCAAG } \\
\text { R: TGGCTCATCAGAGTTCAAC }\end{array}$ \\
\hline $\begin{array}{l}\text { Phosphoenolpyruvate } \\
\text { carboxylase } 2(P E P C)\end{array}$ & $\mathrm{C} 16013 \mathrm{C} 03$ & $\begin{array}{l}\text { Phosphoenolpyruvate carboxylases are key enzymes of } \\
\text { photosynthesis by catalysing the addition of } \mathrm{CO}_{2} \text { to } \\
\text { phosphoenolpyruvate to form the four-carbon } \\
\text { compound oxaloacetate }\end{array}$ & $\begin{array}{l}\text { F: CCAAGCCTACACTCTGAAG } \\
\text { R: TAGGGTTAAGCCTCACAAG }\end{array}$ \\
\hline $\begin{array}{l}\text { Photosystem II reaction } \\
\text { centre W protein } \\
\text { chloroplast precursor } \\
(p s b W)\end{array}$ & C31604G05 & Subunit of the photosystem II & $\begin{array}{l}\text { F: CTGTTGGGTGTTTTTGGTC } \\
\text { R: TGGGTTTGGCTTTAGACTTC }\end{array}$ \\
\hline $\begin{array}{l}\text { CuZn superoxide dismutase } \\
\quad(S O D)\end{array}$ & $\mathrm{C} 31504 \mathrm{C} 12$ & $\begin{array}{l}\text { CuZn superoxide dismutases are mostly involved ROS } \\
\text { detoxication }\end{array}$ & $\begin{array}{l}\text { F: GGAACTGTTTCCTTTAGCG } \\
\text { R: TGCCTATGTTTCCGTAAGTG }\end{array}$ \\
\hline $\begin{array}{l}\text { Dehydroascorbate reductase } \\
\quad(D H A R)\end{array}$ & C31402E11 & $\begin{array}{l}\text { Dehydroascorbate reductase allows the maintaining of an } \\
\text { appropriate level of ascorbate in plant cells that protect } \\
\text { against oxidant injury }\end{array}$ & $\begin{array}{l}\text { F: AGCCCAGAAGGGAAAGTACC } \\
\text { R: AGGCAAATTCAGGAGGATTG }\end{array}$ \\
\hline $\begin{array}{l}\text { Glutathione S-transferase } \\
\quad \text { GST } 22(G S T)\end{array}$ & C07010G07 & $\begin{array}{l}\text { Glutathione S-transferase catalyses the conjugation of } \\
\text { reduced glutathione and favours detoxication of } \\
\text { endogenous compounds such as peroxidized lipids }\end{array}$ & $\begin{array}{l}\text { F: AATCGCGAGCTATCATAAGG } \\
\text { R: CTACTTCCAGCCATTGTTCC }\end{array}$ \\
\hline $\begin{array}{l}\text { Putative fatty acid elongase } \\
\qquad(F A E)\end{array}$ & C32009D10 & $\begin{array}{l}\text { Fatty acid elongase would be involved in bilayer making } \\
\text { as well as in the wax of the cuticle }\end{array}$ & $\begin{array}{l}\text { F: GGGGCTTGAAGAATACAGG } \\
\text { R: AATGCCTCAGCTAAAGAAGG }\end{array}$ \\
\hline \multicolumn{4}{|l|}{ Overexpressed genes } \\
\hline $\begin{array}{l}\text { Chlorophyllide A oxygenase } \\
\text { chloroplast precursor } \\
(C A O)\end{array}$ & C31601G07 & $\begin{array}{l}\text { Chlorophyllide A oxygenase chloroplast precursors are } \\
\text { enzymes involved in chlorophyll } b \text { biosynthesis }\end{array}$ & $\begin{array}{l}\text { F: TACCTATGGAGGCACTTTG } \\
\text { R: CACCCCTAGTTTGTCGTAAC }\end{array}$ \\
\hline $\begin{array}{l}\text { Alternative oxidase } \\
\text { mitochondrial precursor } \\
(A O X)\end{array}$ & KN0AAP7YK07 & $\begin{array}{l}\text { Alternative oxidases are enzymes that provide an } \\
\text { alternative route for electrons passing through the } \\
\text { electron transport chain to reduce oxygen and enhance } \\
\text { an organism's ability to resist stresses through reducing } \\
\text { the level of oxidative stress }\end{array}$ & $\begin{array}{l}\text { F: GCGTAAGTTCCAGCATAGTG } \\
\text { R: CCTCCAAGTAGCCAACAAC }\end{array}$ \\
\hline $\begin{array}{l}\text { Cinnamoyl-CoA } \\
\text { reductase-like protein } \\
(C C R)\end{array}$ & $\mathrm{C} 34205 \mathrm{C} 03$ & $\begin{array}{l}\text { Cinnamoyl-CoA reductases are enzymes that catalyse the } \\
\text { first step of biosynthesis of monoterpenes of lignin }\end{array}$ & $\begin{array}{l}\text { F: CCTTGCAAAGACACTATCTG } \\
\text { R: GATTGAGGGTTCTGTTGAG }\end{array}$ \\
\hline Cuticle protein $(W A X 2)$ & С02002B06 & $\begin{array}{l}\text { Compound of the cuticle on the leaf epidermis that allows } \\
\text { to limit leaf water loss and limit irradiation caused by } \\
\text { the sun }\end{array}$ & $\begin{array}{l}\text { F: CTCGATGGAACACAAAAGG } \\
\text { R: AGTGGTAATGGGTGAAAAGG }\end{array}$ \\
\hline Putative $H V A 22$ gene & C31106H02 & $\begin{array}{l}\text { HVA22 gene was shown to be induced by environmental } \\
\text { stresses, such as dehydration, salinity, and extreme } \\
\text { temperatures, and by a plant stress hormone, abscisic } \\
\text { acid }\end{array}$ & $\begin{array}{l}\text { F: TGGCAAGGGCAAGAACAAG } \\
\text { R: ACAAGCCAACGGAGAATCG }\end{array}$ \\
\hline Dehydrin $(D H)$ & $\mathrm{C} 31207 \mathrm{C} 07$ & $\begin{array}{l}\text { Dehydrins are thermostable hydrophilic proteins that play } \\
\text { a major role of osmoprotectant and stabilize proteins in } \\
\text { stress condition }\end{array}$ & $\begin{array}{l}\text { F: GCCACCGAGTTTGAGAAAG } \\
\text { R: GTGGATCGGTGAAGTTTGTC }\end{array}$ \\
\hline $\begin{array}{l}\text { Delta 1-pyrroline- } \\
\text { 5-carboxylate synthetase } \\
(P 5 C S)\end{array}$ & $\mathrm{C} 34107 \mathrm{H} 03$ & $\begin{array}{l}\text { Delta 1-pyrroline-5-carboxylate synthetase allows } \\
\text { conversion of glutamate to Delta 1-pyrroline-5- } \\
\text { carboxylate to proline that is involved in osmotic stress } \\
\text { tolerance }\end{array}$ & $\begin{array}{l}\text { F: CTAGGAAAGCACCATACGAG } \\
\text { R: GAGGCCCTCTACATCACTC }\end{array}$ \\
\hline $\begin{array}{l}\text { Early-responsive to } \\
\text { dehydration protein } \\
(E R D 4)\end{array}$ & C01019H06 & $\begin{array}{l}\text { Early-responsive to dehydration proteins were shown to } \\
\text { be synthesized in water deficit condition and would } \\
\text { favour protein stabilization }\end{array}$ & $\begin{array}{l}\text { F: CGCTGCCCTGCTACTGTAC } \\
\text { R: CCATGCTAGGGGTTTCCTTC }\end{array}$ \\
\hline Galactinol synthase $(G o L S)$ & C31402D06 & $\begin{array}{l}\text { Galactinol synthase catalyses the first step of the } \\
\text { biosynthesis of raffinose family oligosaccharides, which } \\
\text { are osmoprotectant against water deficit }\end{array}$ & $\begin{array}{l}\text { F: CCATGGCCTATTATGTCATC } \\
\text { R: CATCAGGCAAGTCAAACAG }\end{array}$ \\
\hline $\begin{array}{l}\text { Group I late embryogenesis } \\
\text { abundant protein }(L E A)\end{array}$ & C34209G11 & $\begin{array}{l}\text { Group I late embryogenesis abundant proteins were } \\
\text { shown to synthesize in water deficit condition and } \\
\text { would favour protein stabilization }\end{array}$ & $\begin{array}{l}\text { F: GCGACGGAGAAGAAAGAGG } \\
\text { R: CACCACCCCTTCAATCACC }\end{array}$ \\
\hline Raffinose synthase $(R S)$ & $\mathrm{C} 05076 \mathrm{C} 10$ & $\begin{array}{l}\text { Raffinose synthase enzyme allows the biosynthesis of the } \\
\text { raffinose known to be an osmoprotectant when plants } \\
\text { are subjected to water deficit }\end{array}$ & $\begin{array}{l}\text { F: TCGACGTTATCCATTTGCTG } \\
\text { R: CACCATTGCCCTTGAAGTG }\end{array}$ \\
\hline
\end{tabular}

The rate of expression corresponds to the gene expression in stress condition over control condition from Valencia leaf samplings of 2xRL/V and 4xRL/V (Supporting Information Fig. S2). Annealing temperature was $55^{\circ} \mathrm{C}$. ROS, reactive oxygen species. 
number of potential primer dimers and primer hairpins. Quantitative real-time RT-PCR was performed according to Colmenero-Flores et al. (2007). For each investigated gene, three biological replicates were analysed.

\section{Statistical analysis}

Data are expressed as the mean value \pm SE. SIGMASTAT from SPSS (Chicago; http://www.spss.com_software_science) was used to analyse the data. Analysis of variance (ANOvA) and the Student's $t$-test were used to detect differences between the genotypes and the growing conditions at the usual probability level lower than 0.05 . Data normalization and transformation were performed when needed.

\section{RESULTS}

\section{Tetraploid acquisition and plant genetic constitution}

Using flow cytometry, no $2 \mathrm{x}$ seedling was found among seedlings obtained from seeds of the $4 \mathrm{x}$ mother tree, and no $4 \mathrm{x}$ seedling was found among seedlings obtained from seeds of the $2 \mathrm{x}$ mother tree. Analysis of the genetic constitution of $2 \mathrm{x}$ and $4 \mathrm{x}$ genotypes using SSR molecular markers showed that marker profiles were identical between $2 \mathrm{x}$ and $4 \mathrm{x}$ genotypes (data not shown), proving that the $4 \mathrm{x}$ genotype is an autotetraploid originating from a perfect duplication of a diploid genome.

\section{Growing in control conditions, shoot-water relations of $2 x$ scion are modified when grafted on the $4 x$ rootstock}

To investigate whether $4 \mathrm{xRL}$ rootstock can influence the leaf water content of the scion, different physiological parameters of leaves including the water balance of V/2xRL and V/4xRL trees were investigated. Leaf surface area and fresh weight were not significantly affected by the ploidy level of the rootstocks. Furthermore, the ploidy status of the rootstock did not alter the RWC of the scion leaves (Table 2). Additionally, mature leaf stomatal density and size were not significantly different between V/2xRL and V/4xRL (Table 2). Interestingly, under well-watered conditions, the leaves of V/4xRL trees had a lower stomatal conductance $\left(g_{\mathrm{s}}\right)$ than those of $\mathrm{V} / 2 \times R L$, with values of 94.0 and $126.7 \mathrm{mmol} \mathrm{m}^{-2} \mathrm{~s}^{-1}$, respectively (Fig. 1a).

\section{$4 \mathrm{x}$ rootstock conferred improved tolerance to water deficit}

$\mathrm{V} / 2 \mathrm{xRL}$ and $\mathrm{V} / 4 \mathrm{xRL}$ trees in bagged pots were subjected to 24 $\mathrm{d}$ of water deficit subsequent to $7 \mathrm{~d}$ of control treatment, and after $31 \mathrm{~d}$ the experiment was terminated and the roots and leaves were harvested for ABA analysis; to measure water usage, the pots were weighed. As the pots were bagged, water loss occurred only via the transpiration stream, and pot weight decreased slowly once water was being withheld. Wilting was not observed in either V/2xRL or V/4xRL trees grown in bagged pots even at the end of the experiment (31 d). Even though evolutions in the $g_{\mathrm{s}}$ values of the leaves of the control $\mathrm{V} / 2 \times R L$ and V/4xRL trees were observed due to changes of the greenhouse conditions along the experiment, V/4xRL leaf $g_{\text {s }}$ values remained all the time significantly lower (dark symbols, Fig. 1a). For the stressed trees (open symbols), there was no change until the 16th day of the experiment $(9 \mathrm{~d}$ of water deficit), and $g_{\mathrm{s}}$ reached a plateau on the 18 th day. By the 31 st day, $g_{s}$ continued to decrease to a value below 20 $\mathrm{mmol} \mathrm{m}{ }^{-2} \mathrm{~s}^{-1}$ for $\mathrm{V} / 2 \mathrm{xRL}$ but not for V/4xRL (Fig. 1a). Plotting stomatal conductance versus relative water loss of the pots clearly indicated that $\mathrm{V} / 4 \mathrm{xRL}$ trees presented lower $g_{\mathrm{s}}$ values than $V / 2 x R L$ at initial and more limited water consumption at the end of the experiment (Fig. 1b). When pots were bagged, V/2xRL exhibited a faster decrease in pot weight than $\mathrm{V} / 4 \mathrm{xRL}$, corresponding at the end of the experiment to the higher value of $g_{\mathrm{s}}$ in V/4xRL than in V/2xRL trees. When pots were not bagged, trees experienced a much pronounced and faster water deficit. After an $11 \mathrm{~d}$ water deficit, V/2xRL genotypes were clearly more wilted than V/4xRL (Fig. 1c). The leaf quantum yield of photosystem II ( $\left.\Phi_{\text {PSII }}\right)$ of these trees was also measured. For stressed trees, $\Phi_{\text {PSII }}$ dropped after the decrease in $g_{\mathrm{s}}$, and $\mathrm{V} / 2 \mathrm{xRL}$ trees were more affected by the stress (Fig. 1d). As stomatal conductance is known to be related to ABA content, we measured ABA levels in leaves and roots. In control conditions, V/4xRL leaves contained twice as much ABA than V/2xRL leaves (Fig. 2a) and fivefold more ABA in the roots (Fig. 2b). Under stress conditions, at the end of the experiment, the ABA content was similar in the leaves and roots of $\mathrm{V} / 2 \mathrm{xRL}$ and $\mathrm{V} / 4 \mathrm{xRL}$ trees.

\begin{tabular}{lll}
\hline & V/2xRL (mean $\pm \mathrm{SE})$ & $\mathrm{V} / 4 \times R L($ mean $\pm \mathrm{SE})$ \\
\hline Leaf surface $\left(\mathrm{cm}^{2}\right)$ & $36.02 \pm 1.6 \mathrm{a}$ & $33.96 \pm 1.9 \mathrm{a}$ \\
Leaf thickness $\left(\mathrm{mm}^{2}\right)$ & $0.241 \pm 7 \mathrm{a}$ & $0.254 \pm 6 \mathrm{a}$ \\
Relative water content of the scion & $83.5 \mathrm{a}$ & $84.3 \mathrm{a}$ \\
$\quad$ leaves $(\%)$ & & $310 \pm 19 \mathrm{a}$ \\
Stomata size $\left(\right.$ length $\times$ width $\left.\mu \mathrm{m}^{-2}\right)$ & $290 \pm 25 \mathrm{a}$ & $385 \pm 23 \mathrm{a}$ \\
Stomata density $\left(\right.$ stomates $\left./ \mathrm{mm}^{2}\right)$ & $360 \pm 27 \mathrm{a}$ & \\
\hline
\end{tabular}

Table 2. Surface, thickness and relative water content (RWC) of the Valencia scion leaves, stomatal size, and density in mature leaves of $\mathrm{V} / 2 \times \mathrm{RL}$ and $\mathrm{V} / 4 \mathrm{xRL}$ trees grown in control condition

All values are averages of $10-60$ replicates \pm SE. Data with the same letters are not statistically different. 
pce_12021

6 T. Allario et al.

(a)

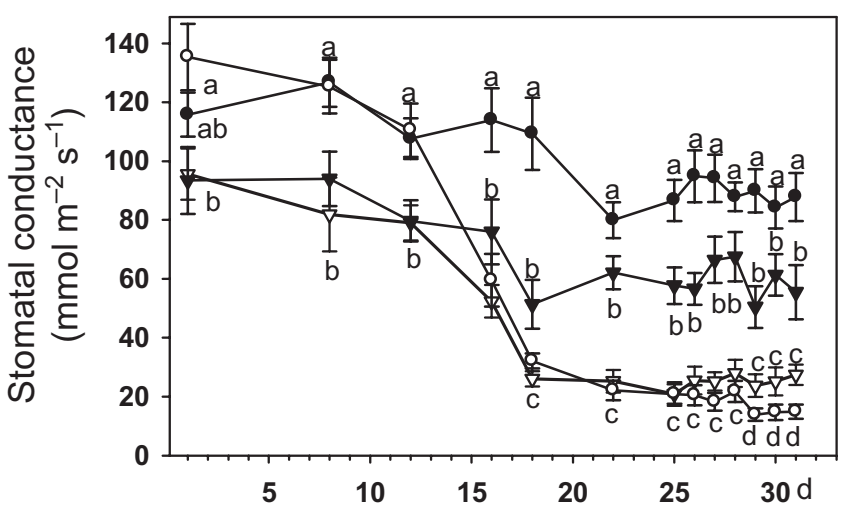

(b)

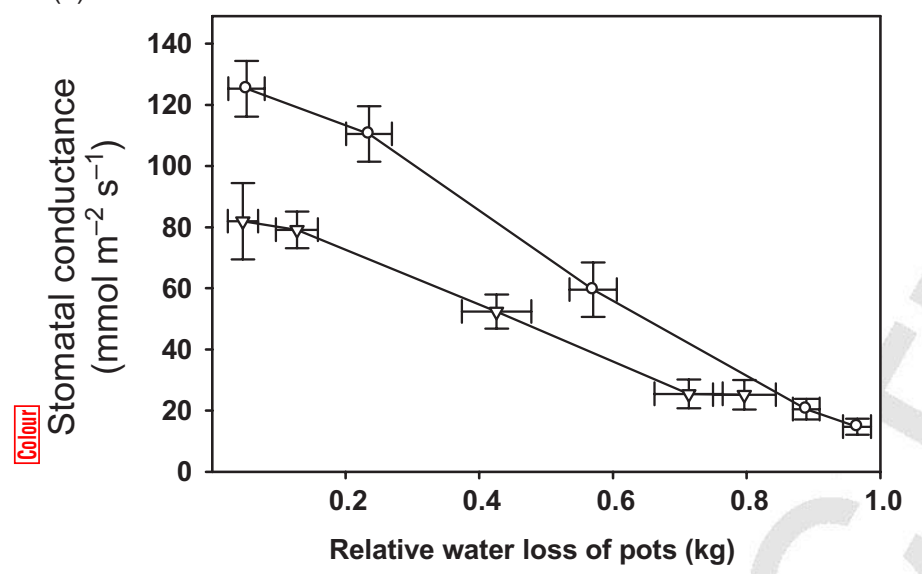

(c)

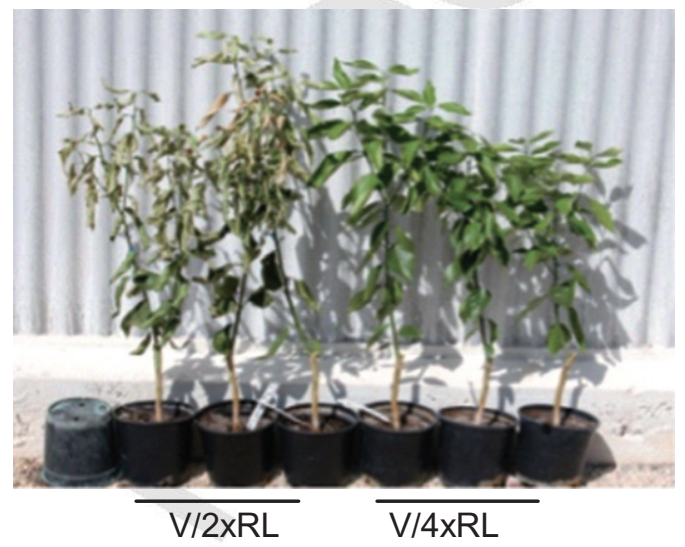

(d)

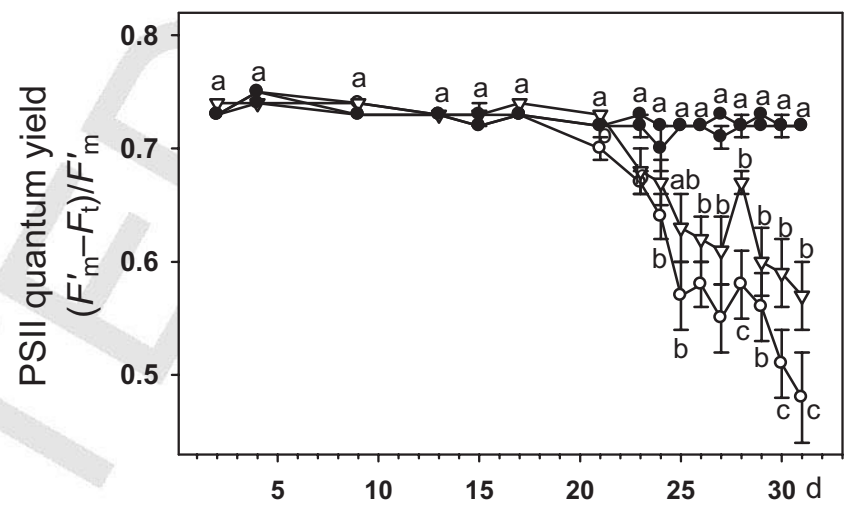

Figure 1. The effect of a water deficit on V/2xRL and V/4xRL. (a) Leaf stomatal conductance $\left(g_{\mathrm{s}}\right)$ of $\mathrm{V} / 2 \times \mathrm{xL}$ and $\mathrm{V} / 4 \mathrm{xRL}$ trees grown in bagged pots in control conditions and subjected to a water deficit for $24 \mathrm{~d}(n=18)$. (b) Stomatal conductance was plotted versus the relative water loss of the pots $(n=6)$. For each genotype, measurements were performed the same day (day 8, day 12, day 16, day 26 and day 30 ). Only day 8 and day 12 did not present a significant difference of relative water loss between V/2xRL and V/4xRL trees. (c) Photograph of $\mathrm{V} / 2 \mathrm{xRL}$ and $\mathrm{V} / 4 \mathrm{xRL}$ trees grown in non-bagged pots after $11 \mathrm{~d}$ of water deficit. (d) Quantum yield of photosystem II (PSII) [( $\left.\left.F_{\mathrm{m}}^{\prime}-F_{\mathrm{t}}\right) / F_{\mathrm{m}}^{\prime}\right]$ measured in the same genotypes $(n=18)$. $(\mathbf{O}: \mathrm{V} / 2 \times R L$, control condition; $\bigcirc: \mathrm{V} / 2 \times R L$, stress condition; $\mathbf{\nabla}: \mathrm{V} / 4 \times \mathrm{RL}$, control condition; $\nabla: \mathrm{V} / 4 \mathrm{xRL}$, stress condition). Data with a different letter are statistically different. Vertical bars indicate the mean value \pm SE.

\section{In control conditions, $4 x$ rootstocks constitutively overexpressed a set of genes involved in water deficit tolerance}

Global gene expression changes induced by water deficit were monitored in the leaves of V/2xRL and V/4xRL bagged trees by microarray hybridization and RT-qPCR. We used samples harvested on the last day of the experiment (timebased comparison) since at this time, V/2xRL trees exhibited a much stronger stress phenotype for water loss and stomatal conductance than V/4xRL trees (Fig. 1a-c). Only information from microarrays with optimal hybridization data was pre-processed and normalized for further analyses (see Materials and Methods section). V/2xRL trees had a greater transcriptional response to water deficit than V/4xRL, because 896 and 342 genes were differentially expressed in the leaves of V/2xRL and V/4xRL, respectively (Fig. 3a). The ratio of induced/repressed genes was $0.48 / 0.52$ and $0.43 / 0.57$ for V/2xRL and V/4xRL trees, respectively (Fig. 3b; see Supporting Information Tables S1 and S2 for detailed lists of differentially expressed genes). Out of the 342 genes differentially expressed in V/4xRL, 230 (67\%) were also differentially expressed in V/2xRL, and the subset of common genes exhibited a similar expression pattern (Supporting Information Fig. S1). Functional categories significantly enriched in the groups of water deficit-induced and -repressed genes were additionally identified through Fisher's exact test with multiple testing correction according to Conesa et al. (2005). Significantly enriched functional categories induced by water deficit were similar in both V/2xRL and V/4xRL trees (Supporting Information Table S3). The most abundant categories in the group of induced genes, common to V/2xRL and $\mathrm{V} / 4 \mathrm{xRL}$ trees, were related to abiotic stress responses, including ABA and water deprivation responses (Fig. $3 \mathrm{c}$ and Supporting Information Table S3). The most significant difference observed in the group of induced genes was related to 'polysaccharide catabolic processes' and related categories, which were significantly enriched in V/2xRL plants but not in V/4xRL plants (Supporting Information Table S3). A different scenario was found in the group of genes repressed

\footnotetext{
() 2012 Blackwell Publishing Ltd, Plant, Cell and Environment 

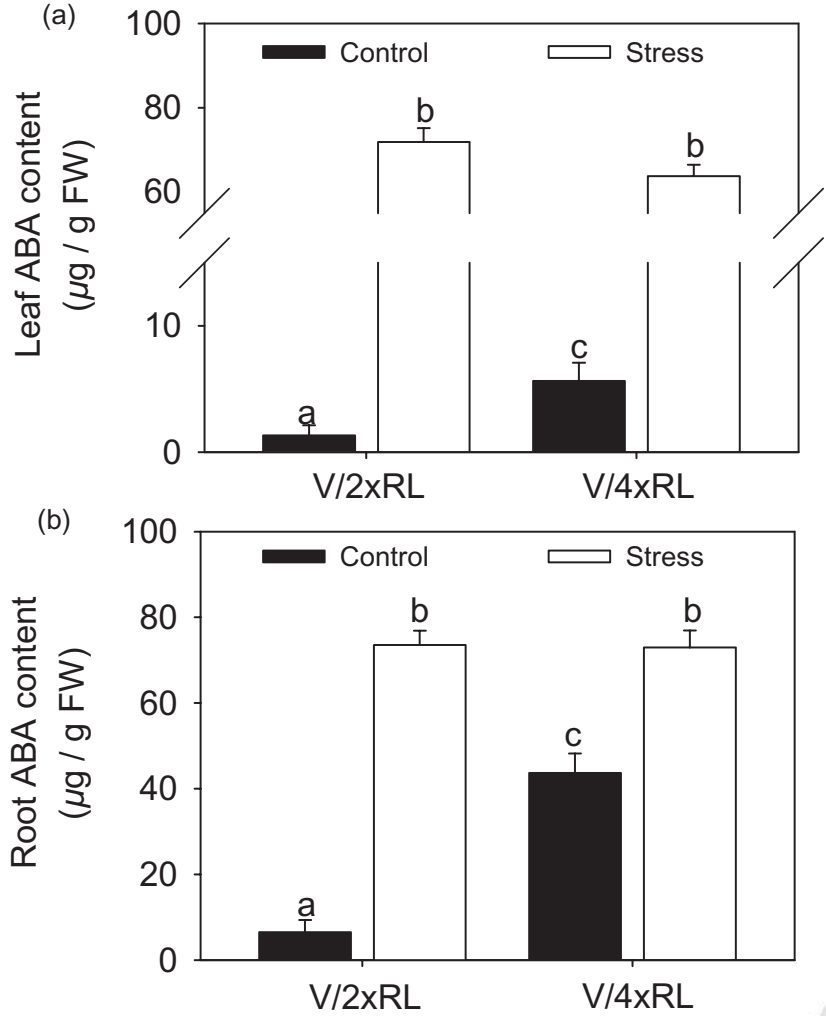

Figure 2. Abscisic acid (ABA) content of $\mathrm{V} / 2 \mathrm{xRL}$ and $\mathrm{V} / 4 \mathrm{xRL}$ organs of trees grown in bagged pots in control conditions and after $24 \mathrm{~d}$ of stress. (a) Leaf ABA content of V/2xRL and V/4xRL trees. (b) Root ABA content of V/2xRL and V/4xRL trees. For each graph, data with different letters are statistically different. Vertical bars indicate the mean value $\pm \operatorname{SE}(n=3)$.

by water deficit because they revealed significant differences between the response to water deficit of V/2xRL and V/4xRL trees (Supporting Information Table S4). Genes related to photosynthesis, carbohydrate metabolism, carbon fixation, jasmonic acid (JA) biosynthesis, response to JA stimulus, response to salicylic acid (SA) stimulus, defence response, JA and ethylene-dependent systemic resistance, and toxin catabolism were significantly more repressed in Valencia grafted onto $2 \mathrm{x}$ rootstocks than $4 \mathrm{x}$ rootstocks (Supporting Information Tables S4 and S5). Other functional categories related to starch biosynthesis and protease inhibitor activities were repressed to a similar extent in both systems (Supporting Information Table S4).

In order to validate the microarray data, transcript abun13 dance of genes associated with photosynthesis, detoxification, cell wall and cuticle biosynthesis, and osmoticum biosynthesis processes (Table 1) was quantified by qRT-PCR in leaf tissues of V/2xRL and V/4xRL challenged with water deficit. Quantitative data were normalized, and the resulting expression values were correlated with the microarray expression $\log (2)$ ratios. The linear regressions indicated a goodness of fit $\left(\mathrm{R}^{2}\right)$ of respectively 0.92 and 0.73 between both kinds of analyses (Supporting Information Fig. S2). The expression of a Citrus NCED1 candidate gene (Agustí et al.2007), which is (c) 2012 Blackwell Publishing Ltd, Plant, Cell and Environment involved in ABA biosynthesis, was also investigated. Quantitative data obtained from down- and up-regulated genes were normalized and the resulting expression log (2) ratios are shown in Fig. 4. Stress/control ratios in the leaves of V/2xRL and V/4xRL trees exhibited similar trends (Fig. 4a) and allowed the microarray results to be confirmed, because the induction and repression patterns obtained with the microarray and qRT-PCR techniques were similar. Stress/ control ratios were also obtained in roots with the same set of genes. As expected, genes involved in photosynthesis and cuticle biosynthesis were hardly expressed in V/2xRL and $\mathrm{V} / 4 \mathrm{xRL}$ roots and are not presented (Fig. $4 \mathrm{~b}$ ). Genes that were up-regulated in response to stress in leaves were also up-regulated in roots. However, genes down-regulated in response to stress in leaves were mostly up-regulated in roots. Notably, 2xRL presented a more pronounced up-regulation of all tested genes in roots than $4 x R L$ genotypes. The CsNCED1 candidate gene was not significantly up- or down-regulated in response to stress in the leaves of $\mathrm{V} / 2 \times R L$ and V/4xRL trees, based on microarray data or RT-qPCR results (Fig. 4a). However, in stress conditions, CsNCED1 was up-regulated in V/2xRL roots (Fig. 4b). For the same set of genes, gene expression ratio of V/4xRL to $\mathrm{V} / 2 \mathrm{xRL}$ leaves and roots was investigated in control and stress conditions. Under control conditions, the gene expression ratios of $\mathrm{V} / 4 \mathrm{xRL}$ to $\mathrm{V} / 2 \mathrm{xRL}$ for leaf samples ranged from -0.8 to 1.5 , and most of them (14 over 20 genes) presented $\log 2$ ratio close to 0 (Fig. 5a). Interestingly, the analysis of the expression ratios of V/4xRL to V/2xRL of the same genes in roots showed a dramatic up-regulation for all genes, except genes involved in photosynthesis and cuticle biosynthesis that were very little expressed and were not represented in Fig. 5a. A comparison of the V/4xRL and V/2xRL gene expression ratios in stressed leaves did not reveal large changes in expression, because the values were less than 1.5 for all of the genes (Fig. 5b). In stressed roots, the expression of genes was greater in V/4xRL than in V/2xRL, but the difference in expression was smaller than in control conditions (Fig. 5b).

\section{DISCUSSION}

\section{What causes the lower $g_{\mathrm{s}}$ values measured in the leaves of V/4XRL trees in control conditions?}

An investigation of the leaf morphology phenotype (leaf area and thickness) of Valencia orange trees grafted onto $2 \mathrm{x}$ and $4 x R L$ rootstocks grown in control conditions did not show any significant difference between the two types of trees. Previous studies performed in polyploids showed that $4 \mathrm{x}$ citrus seedlings present lower rates of whole tree transpiration than $2 \mathrm{x}$, which led to a reduced growth rate (RomeroAranda et al.1997; Allario et al. 2011). We also observed that in $4 \times R L$ seedlings, the reduction of $g_{\mathrm{s}}$ was associated with an increase in stomatal size and a decrease in stomatal density (Allario et al.2011). Before pruning to generate homogenous trees, $\mathrm{V} / 2 \mathrm{xRL}$ trees were taller than those of V/4xRL. Interestingly, the leaf $g_{\mathrm{s}}$ of $\mathrm{V} / 4 \mathrm{xRL}$ was lower than that of $\mathrm{V} / 2 \mathrm{xRL}$ 
(a)

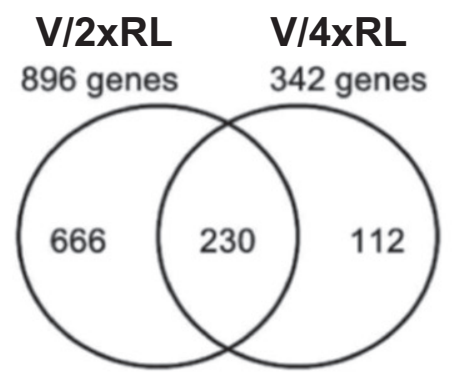

(b)

Drought-responsive genes (c)

\section{Main enriched categories in the induced genes} "group"

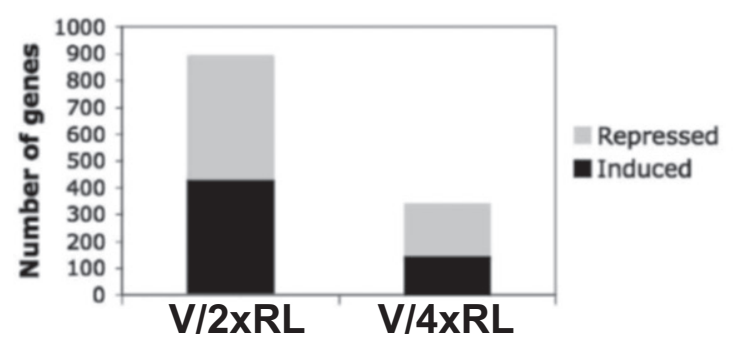

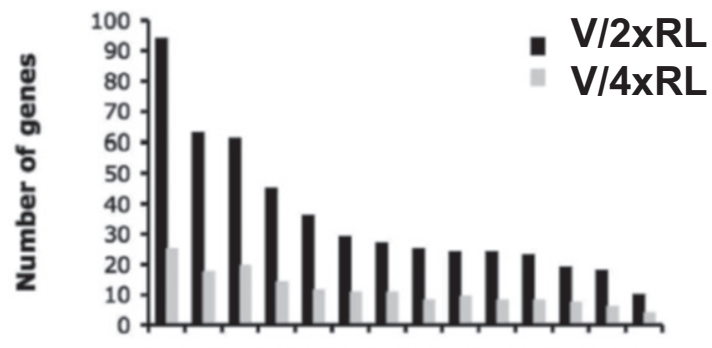

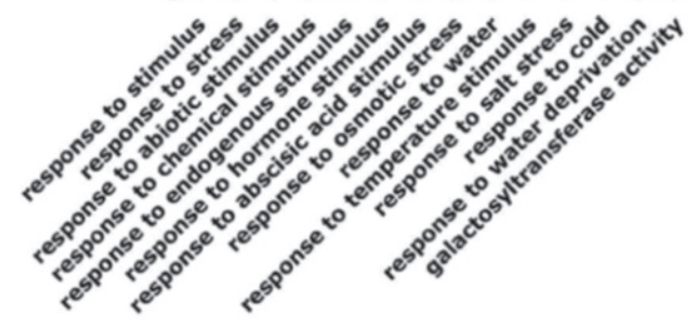

Figure 3. Microarray analysis. (a) The number of genes differentially expressed in the leaves of V/2xRL and V/4xRL trees. (b) Drought responsive genes repressed and induced in V/2xRL and V/4xRL trees subjected to water deficit. (c) Main enriched categories in groups of induced genes.

(Fig. 1a), but was not associated to any difference in stomatal size and density in control mature leaves (Table 2). It seems therefore that the reduced $g_{\mathrm{s}}$ values measured in the leaves of V/4xRL compared with V/2xRL cannot be explained by a change of the anatomy or the morphology of the $2 x$ Valencia leaf whatever the ploidy of the rootstock is. In control conditions, the leaf RWC of both tree associations was not significantly different (Table 2), and most of the gene expression ratios of $\mathrm{V} / 4 \mathrm{xRL}$ to $\mathrm{V} / 2 \mathrm{xRL}$ for leaf samples were close to 1. Then, we postulate that V/4xRL and V/2xRL control trees were not experiencing any stress that may have led to a change of anatomy or morphology of the $2 x$ Valencia leaves. Then, we hypothesize that the lower $g_{s}$ values and lower growth rate observed in V/4xRL trees are caused by the $4 \mathrm{x}$ root system via a root-to-shoot signalling.

Investigations have shown that shoots may sense soil moisture status via the root-to-shoot translocation of a chemical signal before any detectable changes in shoot-water relations are produced (Blackman \& Davies 1985; Gutschick \& Simonneau 2002). Recently, investigations of the herbaceous perennial Chamerion angustifolium L. Holub suggested that the improved tolerance to water stress of $4 \mathrm{x}$ plants is associated with an increased efficiency of absorbing soil moisture before leaf water potentials that cause stomatal closure are reached (Maherali, Walden \& Husband 2009). Regarding the plant water status, ABA is the main hormonal signal in rootshoot communication (Tardieu \& Davies 1992; Dodd 2003, 2005). However, it has been shown that grafting a wild-type scion onto an ABA-deficient rootstock generally has no effect on stomatal conductance or whole plant transpiration rate, implying that wild-type shoots can synthesize enough
ABA to control their water balance (Holbrook et al. 2002; Dodd et al. 2009). Our results showed that V/4xRL trees had a higher level of ABA than V/2xRL, not only in the leaves but also in the root (Fig. 2). As control trees were watered at field capacity to prevent any water deficit, we suggest that the higher ABA levels measured in leaves of V/4xRL originated in the root system and that ABA was transported to the shoot through the transpiration stream. Consequently, we hypothesize that this higher leaf ABA content may contribute to the regulation of stomatal conductance in the $4 \mathrm{x}$ genotype, minimizing the tree's water loss and decreasing its growth rate (Figs $1 \mathrm{~b}$ and 6a). Recent experiments (Martin-Vertedor \& Dodd 2011) also show that ABA supplied to the xylem of detached barley (Hordeum vulgare) shoots decreases shoot growth by $40 \%$ in a short-term $(6 \mathrm{~h})$ experiment. We can of course not exclude that the use of $4 x$ rootstock may lead to other physiological changes such as the root hydraulic resistance or hormonal balance that may affect the growth rate of the tree.

\section{Gene expression profiling demonstrated that V/2xRL plants were more affected by stress than V/4XRL}

The purpose of monitoring gene expression in the clonal $2 x$ Valencia orange variety was to characterize the impact of using a $4 \mathrm{x}$ rootstock compared with a $2 \mathrm{x}$ rootstock on gene expression in leaves without any interference of leaf polyploidy status. Besides the physiological evidence that V/4xRL trees are better adapted to drought than are V/2xRL trees (Fig. 1), the higher number of differentially expressed genes 
(a)

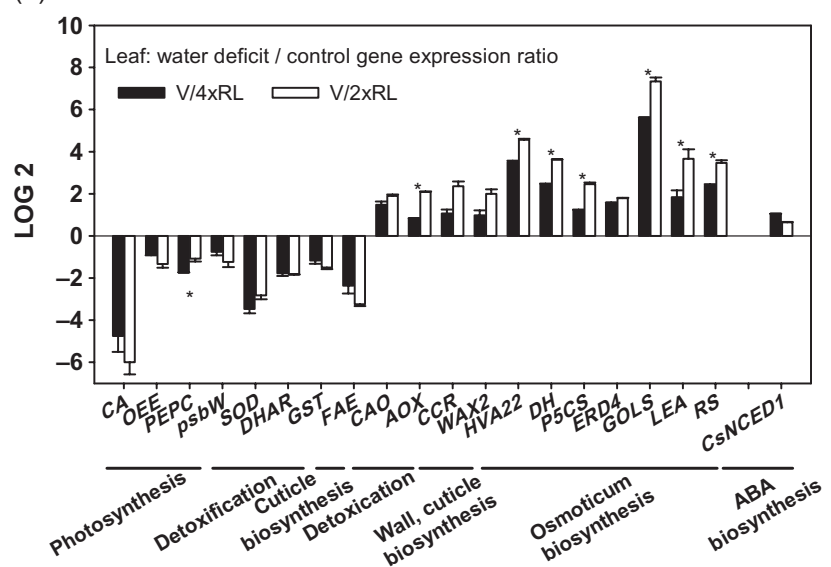

(b)

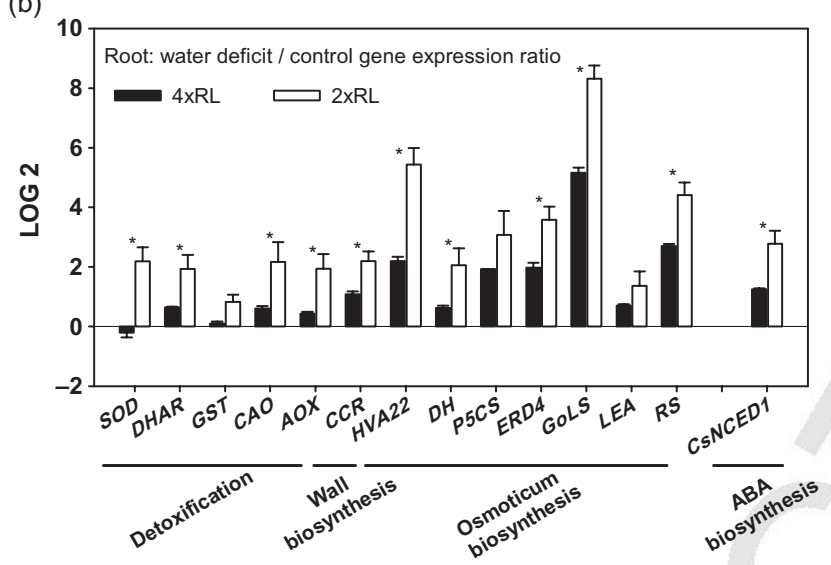

Figure 4. Gene expression, as determined by qRT-PCR, in the leaves and roots of V/2xRL and V/4xRL trees. (a) Gene expression in the leaves of V/2xRL and V/4xRL genotypes. Results are presented as a water deficit condition/control condition gene expression ratio. (b) Gene expression in the roots of V/2xRL and $\mathrm{V} / 4 x R L$ genotypes. Results are presented as a water deficit condition/control condition gene expression ratio. Vertical bars indicate the mean_ $\pm \mathrm{SE}(n=3)$. For each gene, $*$ indicates a significant difference ( $t$-test) between $\mathrm{V} / 2 \times \mathrm{xL}$ and $\mathrm{V} / 4 \mathrm{xRL}$ genotypes $(P<0.05)$. Gene name and function are presented in Table 1.

involved in the response to water deficit (threefold greater in V/2xRL; Fig. 3) indicated that V/2xRL trees were responding more strongly to stress than V/4xRL. Indeed, as V/2xRL and $\mathrm{V} / 4 \mathrm{xRL}$ trees did not present the same water consumption, trees were subjected to different soil water status when samples were harvested. Logically, V/4xRL trees, which have taken up less water, appeared less affected by stress than $\mathrm{V} / 2 \mathrm{xRL}$ trees. As a consequence, the leaf water potential of $\mathrm{V} / 2 \times \mathrm{RL}$ was probably lower than V/4xRL. It can be hypothesized that the better tolerance observed in V/4xRL is associated to avoidance mechanisms (Verslues et al. 2006), because in control condition root anatomy and morphology of $2 \mathrm{x}$ and $4 \mathrm{xRL}$ seedlings were very different (Allario et al. 2011). Indeed, we observed that the growth of 2xRL was more vigorous than $4 \mathrm{x}$, although roots of $4 \mathrm{x}$ plants were thicker and contained larger cells than $2 \mathrm{x}$, which may have a large impact on cell-to-cell water exchanges leading to possible changes of hydraulic resistance in control and water deficit condition.

About $70 \%$ of the genes differentially expressed in the leaves of $\mathrm{V} / 4 \mathrm{xRL}$ trees were also differentially expressed in $\mathrm{V} / 2 \mathrm{xRL}$, indicating that $\mathrm{V} / 4 \mathrm{xRL}$ also responded to the drought treatment. This is evidenced by (1) the similar pattern of expression exhibited by the common set of genes differentially expressed between drought and control conditions in both genotypes (Supporting Information Fig. S1); and (2) the nature of the most important sets of genes induced in both V/2xRL and V/4xRL trees, which include functional categories such as 'response to ABA stimulus', 'response to osmotic stress' and 'response to water' (Fig. 3c and Supporting Information Table S3). Interestingly, clear differential responses were observed in the leaves of V/2xRL and V/4xRL trees, according to the sets of repressed genes. Functional categories mainly related to metabolic processes such as photosynthesis, carbon utilization and fatty acid biosynthesis were much more severely repressed in V/2xRL
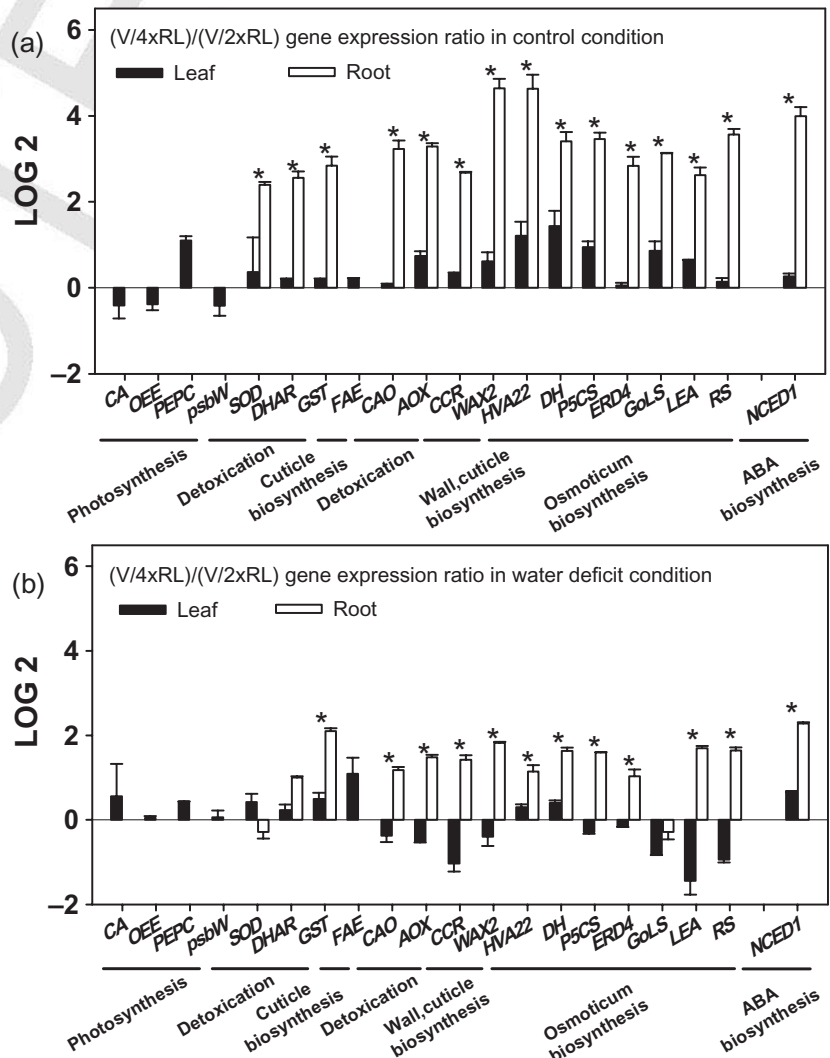

Figure 5. Gene expression, as determined by qRT-PCR, in the leaves and roots of V/2xRL and V/4xRL trees. (a) Gene expression in the leaves and roots of $\mathrm{V} / 2 \times R L$ and $V / 4 \times R L$ genotypes grown in control conditions. Results are presented as the ratio of 4xRL/2xRL gene expression. (b) Gene expression in the leaves and roots of $\mathrm{V} / 2 \times \mathrm{xL}$ and $\mathrm{V} / 4 \mathrm{xRL}$ genotypes in water deficit conditions. Results are presented as a 4xRL/2xRL gene expression ratio. Vertical bars indicate the mean $\pm \mathrm{SE}(n=3)$. For each gene, * indicates a significant difference $(t$-test) between the leaf and the root $(P<0.05)$. Gene name and function are presented in Table 1 . 
(a)

$$
2 \times R L / V
$$

4xRL/V

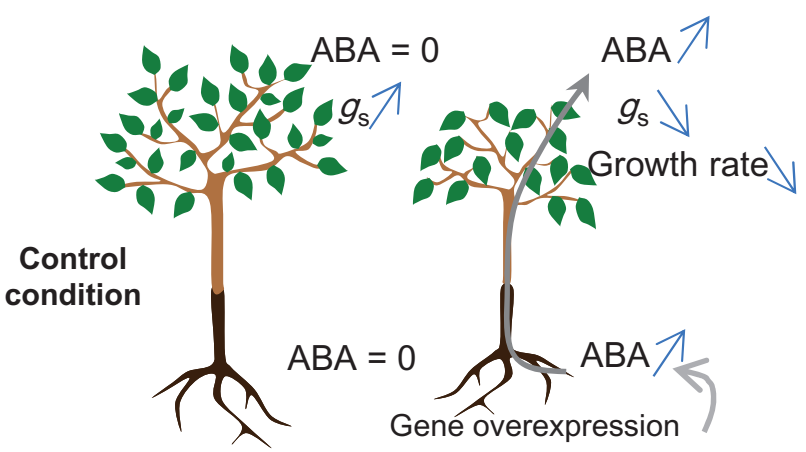

(b)

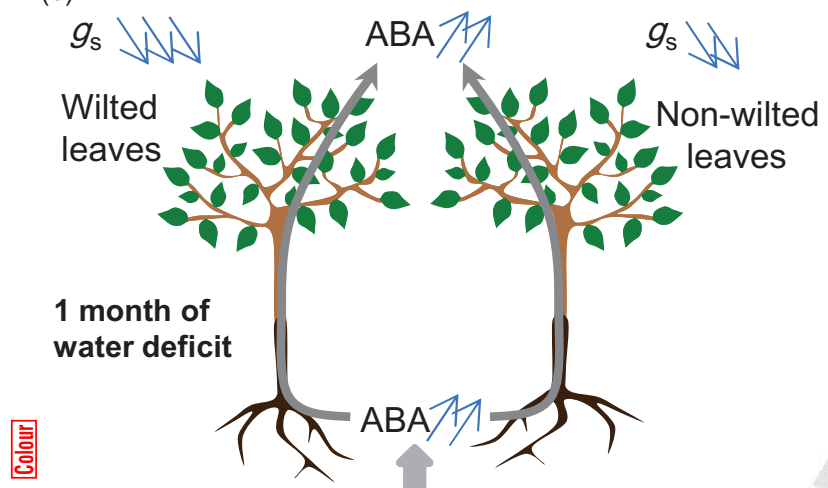

Root overexpression of genes involved in water deficit tolerance

Figure 6. Schematic model of growth, $g_{\mathrm{s}}$ responses and root gene expression in $\mathrm{V} / 2 \times R L$ and $\mathrm{V} / 4 \mathrm{xRL}$ trees under non-stressed and water-stressed conditions. (a) In well-watered (control) conditions using rootstock/scion associations of the same age, $\mathrm{V} / 2 \mathrm{xRL}$ presented greater vigour than $\mathrm{V} / 4 \mathrm{xRL}$. $\mathrm{V} / 4 \mathrm{xRL}$ trees had higher root abscisic acid (ABA) contents than $\mathrm{V} / 2 \mathrm{xRL}$ trees; $\mathrm{ABA}$ is transferred to the shoot, leading to lower $g_{\mathrm{s}}$ values and slower tree growth rate. Whatever the size of the tree is, the higher ABA contents in $4 \mathrm{x}$ roots correlated with the constitutive overexpression of numerous genes, such as NCED1, that are involved in ABA biosynthesis. (b) When $V / 2 \times R L$ and $V / 4 \times R L$ trees of the same size were subjected to water deficit, V/2xRL trees had lower $g_{\mathrm{s}}$ values than $\mathrm{V} / 4 \mathrm{xRL}$ at the end of the experiment. In addition, wilted leaves were observed in V/2xRL because higher $g_{\mathrm{s}}$ and higher water consumption occurred in V/2xRL during the first days of the stress, demonstrating the increased tolerance to drought of $4 \mathrm{x}$ rootstock/scion associations.

than in V/4xRL trees. This may be linked to the repression of central metabolic processes, which can be considered to be secondary responses common to different stress factors. Inhibition of photosynthetic and carbon metabolism at the transcriptional level is known to be a general response of herbaceous (Xiong et al. 2001; Xiong, Li \& Zhang 2006) and woody plants like Citrus (Forment et al. 2005; Christmann et al. 2007) to water deficit and osmotic stress. This differential response is likely due to a greater soil water deficit that suffered V/2xRL compared with V/4xRL trees and supports the hypothesis that water deficit is more efficiently avoided when citrus is grafted onto $4 \mathrm{x}$ rootstocks.
In addition, the inhibition of photosynthetic and carbon metabolism at the transcriptional level in water-stressed $\mathrm{V} / 2 \mathrm{xRL}$ trees could be the consequence of the stronger reduction of stomatal conductance leading quickly to a decrease of photosynthesis and carbon metabolism (Figs 1a, $1 \mathrm{~b}$ and 5).

\section{What is the molecular origin of the improved tolerance of V/4XRL to water deficit?}

$4 \times R L$ arise from chromosome set doubling of nucellar cells (maternal tissue) (Cameron \& Soost 1969). Consequently, in RL it is possible to compare the phenotypes and transcriptomes of $4 \mathrm{x}$ versus $2 \mathrm{x}$ genotypes immediately after the tetraploidization event. Spontaneous doubled diploid clones obtained from specific diploid citrus species are considered to be genetically identical to each other, with the same genome expression profile. Indeed, in autopolyploids genotypes including RL, gene expression changes in leaves were shown to be very limited when compared with the respective diploid parental (Stupar et al. 2007; Riddle et al. 2010; Allario et al. 2011; Li et al. 2012).

The study of differentially expressed genes obtained from microarray experiments contributed to the understanding of the observed responses of V/2xRL versus V/4xRL both in a quantitative and a qualitative manner. Quantitatively, the genetic response was stronger in V/2xRL in terms of total number of differentially expressed genes, suggesting a greater sensitivity to water deficit in plants grafted onto the diploid rootstock. Qualitatively, the response of V/4xRL affected more specifically the expression of genes that are directly involved in abiotic stress acclimatization processes. This statement is based on the fact that the relative abundance of functional categories specifically induced by abiotic (ABA, drought or osmotic) stimuli was more important in $\mathrm{V} / 4 \mathrm{xRL}$ than in V/2xRL trees (Supporting Information Table S5). We recently reported a similar genomic approach, comparing global gene expression in the leaves of $2 x R L$ versus 4xRL seedlings under control conditions (Allario et al. 2011), showing that large changes in anatomy and physiology between $\mathrm{V} / 2 \times \mathrm{RL}$ and $\mathrm{V} / 4 \mathrm{xRL}$ were not associated with large changes in leaf gene expression. We observed that 'response to ABA stimulus' was a relevant functional category overexpressed in the leaves of $4 x R L$ trees compared with those of 2xRL under control conditions. On the other side, repression of primary metabolic processes like photosynthesis and carbohydrate metabolism can be considered a less specific or secondary response common to other plant species and perturbing factors (Kawasaki et al. 2001; Ozturk et al. 2002; Seki et al. 2002; Sahi et al. 2003; Khelil, Menu \& Ricard 2007; 14 Brumós et al. 2009), which is indicative of a plant that is experiencing a stressful situation. According to microarray results, this phenomenon is clearly produced in diploidgrafted rather than autotetraploid-grafted plants. Altogether, these results support the notion of a preaclimatacion of autotetraploid-grafted plants that make the trees more tolerant water deficit.

(C) 2012 Blackwell Publishing Ltd, Plant, Cell and Environment

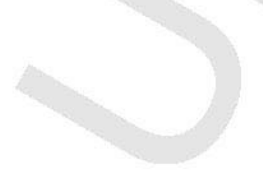


Franck (1980) investigated the water deficit tolerance of wheatgrass polyploids. This study reported the photosynthetic activity in control and water deficit conditions of hexaploid (6x) and $4 \mathrm{x}$ genotypes that exhibited increased drought tolerance levels that were associated with a higher capacity to fix $\mathrm{CO}_{2}$, yet at least in the early stages of drought stomatal conductance closed more sensitively in response to soil drying (Xiong et al. 2006) showed that 6x wheat lines were more tolerant to water deficit than $4 \mathrm{x}$, and that $4 \mathrm{x}$ genotypes were more tolerant than $2 \mathrm{x}$. When subjected to a progressive water deficit, $6 \mathrm{x}$ wheat lines decreased their stomatal conductance before the $4 \mathrm{x}$ and $2 \mathrm{x}$ wheat lines did. In these studies, polyploids were able to maintain a constant leaf RWC longer than $2 \mathrm{x}$ plants, indicating a more sensitive response to root-toshoot chemical signalling (likely ABA) rather than to a hydraulic signal (Xiong et al.2001). Citrus CsNCED1, which is the ortholog of $A t N C E D 3$, was shown to be up-regulated in response to stress (Agustí et al. 2007) and was dramatically up-regulated in $4 \mathrm{x}$ roots relative to $2 \mathrm{x}$ roots in control conditions (Fig. 5a), which is in agreement with the greater ABA contents we measured (Fig. 2). The increased expression of stress-responsive genes in the roots of $4 x$ trees compared with those of $2 x$ trees (Figs 5a and 6a) suggests that V/4xRL citrus trees are better able to withstand water shortage than are $\mathrm{V} / 2 \mathrm{xRL}$, as previously proposed (Allario et al.2011). This is in contrast to the limited change in gene expression observed in the leaves of $2 x$ and $4 x R L$ seedlings under control conditions (Allario et al.2011), suggesting that differential gene expression occurs between the leaves and roots of V/2xRL and V/4xRL trees. Recently, Li et al. (2012) tested 2x and 4x A. thaliana with respect to the gene expression under control compared with mannitol or glucose conditions. Interestingly, the overall changes of gene expression between $2 \mathrm{x}$ and $4 \mathrm{x}$ in mannitol treatment were milder than in glucose treatment. They conclude that the response of the $4 \mathrm{x}$ plants to glucose treatment is endogenously different from the $2 \mathrm{x}$ plants. Indeed, these authors observed that during root development, the difference of root cell size and cell number between $2 x$ and the $4 \mathrm{x}$ under the glucose treatment was significant, but that under mannitol was not. The two water deficit experiments we performed in citrus lasted for 11 and $24 \mathrm{~d}$, respectively. The same phenotype of better adaptation of V/4xRL compared with V/2xRL was observed in both experiments. Because citrus are slow-growing plants, we can hypothesize that no large changes of cell size and anatomy induced by stress may have occurred in roots during the experiments. Therefore, the higher ABA content measured in roots of V/4xRL in control condition would be a direct consequence of the constitutive overexpression of CSNCED1 in 4x roots.

Under water deficit conditions, the gene expression ratio of stressed leaves to control leaves was not significantly changed, regardless of the ploidy status of the rootstock, except for a few genes that were expressed at greater levels in V/2xRL. As expected, the genes of water-stressed trees showed a greater level of overexpression in the roots of $\mathrm{V} / 2 \mathrm{xRL}$ trees than of $\mathrm{V} / 4 \mathrm{xRL}$, confirming that a variety grafted onto a $2 \mathrm{x}$ rootstock is more sensitive to drought than when grafted onto a $4 \mathrm{x}$ rootstock (Fig. 6b).
Our results support the interpretation that long-distance ABA signalling from root to shoot leads to important changes in shoot physiology when plants are experiencing water deficit, although ABA signalling may not be sufficient by itself (Christmann et al. 2007) and may be modified by other factors (Dodd et al. 2009). We could not find other studies in which this type of signalling has been described in two genotypes ( $2 x$ and $4 x R L$ roots) that are genetically identical but with a different level of ploidy. In $4 x R L$, this rootto-shoot signalling is mediated by a constitutive differential expression of several genes, including the CSNCED1 gene, which led to increased root-to-shoot transfer of ABA, and consequently was at the origin of greater regulation of gas exchange of scions grown on $4 \mathrm{x}$ root genotypes. Therefore, the use of autotetraploid citrus genotypes as rootstock is a powerful technique for demonstrating the importance of root-to-shoot signalling and the consequences on plant physiology. Further investigations are now needed to better understand the differential regulation of genes in autotetraploid roots compared with diploid roots.

\section{FUNDING}

This work was supported by the European 'INCO' project (FP6-2003-INCO-DEV-2 no. 015453) to T.A. and by funds from IVIA to J.B. Additional funds were provided by the Spanish Ministerio de Ciencia e Innovación-FEDER grant (AGL2007-65437-C04-01/AGR, AGL2008-00596/AGR and AGL2009-08339/AGR) and a Prometeo 2008/121 Generalidad Valenciana grant.

\section{ACKNOWLEDGMENTS}

We thank I. Dodd and M.J. Chrispeels for helpful discussion.

\section{REFERENCES}

Adams K.L., Cronn R., Percifield R. \& Wendel J.F. (2003) Genes duplicated by polyploidy show unequal contributions to the transcriptome and organspecific reciprocal silencing. Proceedings of the National Academy of Sciences of the United States of America 100, 4649-4654.

Agustí J., Zapater M., Iglesias D.J., Cercós M., Tadeo F.R. \& Talón M. (2007) Differential expression of putative 9-cis-epoxycarotenoid dioxygenases and abscisic acid accumulation in water stressed vegetative and reproductive tissues of citrus. Plant Science 172, 85-94.

Aleza P., Froelicher Y., Schwarz S., Agusti M., Hernandez M., Juarez J., Luro F., Morillon R., Navarro L. \& Ollitrault P. (2011) Tetraploidization events by chromosome doubling of nucellar cells are frequent in apomictic citrus and are dependent on genotype and environment. Annals of Botany 108, 37 50 .

Allario T., Brumos J., Colmenero-Flores J.M., Tadeo F., Froelicher Y., Talon M., Navarro L., Ollitrault P. \& Morillon R. (2011) Large changes in anatomy and physiology between diploid Rangpur lime (Citrus limonia) and its autotetraploid are not associated with large changes in leaf gene expression. Journal of Experimental Botany 62, 2507-2519.

Ashburner M., Ball C.A., Blake J.A., et al. (2000) Gene ontology: tool for the unification of biology. Nature Genetics 25, 25-29.

Auger D.L., Peters E.M. \& Birchler J.A. (2005) A genetic test of bioactive gibberellins as regulators of heterosis in maize. The Journal of Heredity 96, 614-617.

Barr H.D. \& Weatherly P.E. (1962) A re-examination of the relative turgidity technique for estimating water deficit in leaves. Australian Journal of Biological Sciences 15, 413-428. 
Barrett H.C. \& Hutchinson D.J. (1982) Occurrence of spontaneous octoploidy in apomictic seedlings of a tetraploid citrus hybrid. Proceedings of the International Society of Citriculture 1, 29-30.

Benjamini Y. \& Hochberg Y. (1995) Controlling the false discovery rate: a practical and powerful approach to multiple testing. Journal of the Royal Statistical Society, Series B 57, 289-300.

Blackman P.G. \& Davies W.J. (1985) Root to shoot communication in maize plants of the effects of soil drying. Journal of Experimental Botany 36, 39-48.

Bluthgen N., Kielbasa S.M. \& Herzel H. (2005) Inferring combinatorial regulation of transcription in silico. Nucleic Acids Research 33, 272-279.

Brumós J., Colmenero-Flores J.M., Conesa A., Izquierdo P., Sánchez G., Iglesias D.J., López-Climent M.F., Gómez-Cadenas A. \& Talón M. (2009) Membrane transporters and carbon metabolism implicated in chloride homeostasis differentiate salt stress responses in tolerant and sensitive Citrus rootstocks. Functional and Integrative Genomics 9, 293-309.

Cameron J.W. \& Soost R.K. (1969) Characters of new populations of Citrus polyploids, and the relation between tetraploidy in the pollen parent and hybrid tetraploid progeny. In Proceedings of the International Citric Symposium (ed. H.D. Chapman) Vol. 1, pp. 199-205. University of California Riverside, CA.

Chen Z.J. (2010) Molecular mechanisms of polyploidy and hybrid vigor. Trends in Plant Science 15, 57-71.

Christmann A., Weiler E.W., Steudle E. \& Grill E. (2007) A hydraulic signal in root-to-shoot signalling of water shortage. The Plant Journal 52, 167-174.

Colmenero-Flores J.M., Martinez G., Gamba G., Vazquez N., Iglesias D.J., Brumos J. \& Talon M. (2007) Identification and functional characterization of cation-chloride cotransporters in plants. The Plant Journal 50, 278292.

Conesa A., Gotz S., Garcia-Gomez J.M., Terol J., Talon M. \& Robles M. (2005) Blast2GO: a universal tool for annotation, visualization and analysis in functional genomics research. Bioinformatics 21, 3674-3676.

Dambier D., Benyahia H., Pensabene-Bellavia G., et al. (2011) Somatic hybridization for Citrus rootstock breeding: an effective tool to solve some important issues of the Mediterranean citrus industry. Plant Cells Report 30, 883-900.

Dodd I.C. (2003) Hormonal interactions and stomatal responses. Journal of Plant Growth Regulation 22, 32-46.

Dodd I.C. (2005) Root-to-shoot signalling: assessing the roles of 'up' in the up and down world of long-distance signalling in planta. Plant and Soil 274, 251-270.

Dodd I.C., Theobald J.C., Richer S.K. \& Davies W.J. (2009) Partial phenotypic reversion of ABA-deficient flacca tomato (Solanum lycopersicum) scions by a wild-type rootstock: normalizing shoot ethylene relations promotes leaf area but does not diminish whole plant transpiration rate. Journal of Experimental Botany 60, 4029-4039.

Edgar R., Domrachev M. \& Lash A.E. (2002) Gene Expression Omnibus NCBI gene expression and hybridization array data repository. Nucleic Acids Research. 30, 207-210.

Forment J., Gadea J., Huerta L., et al. (2005) Development of a citrus genomewide EST collection and cDNA microarray as resources for genomic studies. Plant Molecular Biology 57, 375-391.

Franck A.B. (1980) Photosynthesis, transpiration and ribulose biphosphate carboxylase of selected crested wheatgrass plants. Agronomy Journal 72, 313-316.

Froelicher Y., Bassene J.B., Jedidi-Neji E., Dambier D., Morillon R., Bernardini G., Costantino G. \& Ollitrault P. (2007) Induced parthenogenesis in mandarin for haploid production: induction procedures and genetic analysis of plantlets. Plant Cell Reports 26, 937-944.

Grosser J.W. \& Chandler J.L. (2003) New citrus rootstocks via protoplas fusion. Acta Horticulturae 622, 491-497.

Grosser J.W. \& Gmitter F.G. (2011) Protoplast fusion in the production of tetraploids and triploids: applications in scion and rootstock breeding. Plant Cell Tissue and Organ Culture 104, 343-357.

Gutschick V.P. \& Simonneau T. (2002) Modelling stomatal conductance of field-grown sunflower under varying soil water content and leaf environment: comparison of three models of stomatal response to leaf environment and coupling with an abscisic acid-based model of stomatal response to soil drying. Plant, Cell \& Environment 25, 1423-1434.

Holbrook N.M., Shashidhar V.R., James R.A. \& Munns R. (2002) Stomatal control in tomato with ABA-deficient roots: response of grafted plants to soil drying. Journal of Experimental Botany 53, 1503-1514.

Hussain S., Curk F., Dhuique-Mayer C., Urban L., Ollitrault P., Luro F. \& Morillon R. (2012) Autotetraploid trifoliate orange (Poncirus trifoliato) rootstocks do not impact clementine quality but reduce fruit yields and highly modify rootstock/scion physiology. Scientia Horticulturae 134, 100107.

Kawasaki S., Borchert C., Deyholos M., Wang H., Brazille S., Kawai K., Galbraith D. \& Bohnert H.J. (2001) Gene expression profiles during the initial phase of salt stress in rice. The Plant Cell 13, 889-906.

Khelil A., Menu T. \& Ricard B. (2007) Adaptive response to salt involving carbohydrate metabolism in leaves of a salt-sensitive tomato cultivar. Plant Physiology and Biochemistry 45, 551-559.

Li X., Yu E., Fan C., Zhang C., Fu T. \& Zhou Y. (2012) Developmental, cytological and transcriptional analysis of autotetraploid Arabidopsis. Planta 236, 579-596.

Liu Z. \& Adams K.L. (2007) Expression partitioning between genes duplicated by polyploidy under abiotic stress and during organ development. Current Biology 17, 1669-1674.

Lukens L.N., Pires J.C., Leon E., Vogelzang R., Oslach L. \& Osborn T. (2006) Patterns of sequence loss and cytosine methylation within a population of newly resynthesized Brassica napus allopolyploids. Plant Physiology 140, 336-348.

Maherali H., Walden A.E. \& Husband B.C. (2009) Genome duplication and the evolution of physiological responses to water stress. The New Phytologist 184, 721-731.

Martinez-Godoy M.A., Mauri N., Juarez J., Marques M.C., Santiago J., Forment J. \& Gadea J. (2008) A genome-wide $20 \mathrm{~K}$ citrus microarray for gene expression analysis. BMC Genomics $\mathbf{9}, 318$

Martin-Vertedor A.I. \& Dodd I.C. (2011) Root-to-shoot signalling when soil moisture is heterogeneous: increasing the proportion of root biomass in drying soil inhibits leaf growth and increases leaf abscisic acid concentration. Plant, Cell \& Environment 34, 1164-1175.

Masterson J. (1994) Stomatal size in fossil plants: evidence for polyploidy in majority of angiosperms. Science 264, 421-424.

Morillon R. \& Chrispeels M.J. (2001) The role of ABA and the transpiration stream in the regulation of the osmotic water permeability of leaf cells. Proceedings of the National Academy of Sciences of the United States of America 98, 14138-14143.

Myhre S., Tveit H., Mollestad T. \& Laegreid A. (2006) Additional gene ontology structure for improved biological reasoning. Bioinformatics 22, 20202027

Ni Z., Kim E.D., Ha M., Lackey E., Liu J., Zhang Y., Sun Q. \& Chen Z.J. (2009) Altered circadian rhythms regulate growth vigour in hybrids and allopolyploids. Nature 457, 327-331.

Ozturk Z.N., Talamè V., Deyholos M., Michalowski C.B., Galbraith D.W., Gozukirmizi N., Tuberosa R. \& Bohnert H.J. (2002) Monitoring large-scale changes in transcript abundance in drought- and salt-stressed barley. Plant Molecular Biology 48, 551-573.

Quevillon E., Silventoinen V., Pillai S., Harte N., Mulder N., Apweiler R. \& Lopez R. (2005) InterProScan: protein domains identifier. Nucleic Acids Research 33, W116-W120.

Ramsey J. (2011) From the cover: polyploidy and ecological adaptation in wild yarrow. Proceedings of the National Academy of Sciences of the United States of America 108, 7096-7101.

Rapp R.A., Udall J.A. \& Wendel J.F. (2009) Genomic expression dominance in allopolyploids. BMC Biology 7, 18.

Reiner A., Yekutieli D. \& Benjamini Y. (2003) Identifying differentially expressed genes using false discovery rate controlling procedures. Bioinformatics 19, 368-375.

Riddle N.C., Jiang H., An L., Doerge R.W. \& Birchler J.A. (2010) Gene expression analysis at the intersection of ploidy and hybridity in maize. TAG. Theoretical and Applied Genetics. Theoretische und angewandte Genetik 120, 341-353.

Romero-Aranda R., Bondada B.R., Syvertsen J.P. \& Grosser J.W. (1997) Leaf characteristics and net gas exchange of diploid and autotetraploid citrus. Annals of Botany 79, 153-160.

Sahi C., Singh A., Blumwald E. \& Grover A. (2006) Beyond osmolytes and transporters: novel plant salt-stress tolerance-related genes from transcriptional profiling data. Physiologia Plantarum 127, 1-9.

Saleh B., Allario T., Dambier D., Ollitrault P. \& Morillon R. (2008) Tetraploid citrus rootstocks are more tolerant to salt stress than diploid. Comptes Rendus Biologies 331, 703-710.

Seki M., Narusaka M., Ishida J., et al. (2002) Monitoring the expression profiles of 7000 Arabidopsis genes under drought, cold and high-salinity stresses using a full-length cDNA microarray. The Plant Journal 31, 279292

(C) 2012 Blackwell Publishing Ltd, Plant, Cell and Environment 
Smyth G. (2005) LIMMA: linear models for microarray data. In Bioinformatics and Computational Biology Solutions Using $R$ and Bioconductor (eds $\mathrm{R}$. Gentleman, V. Carey, W. Huber, R. Irizarry \& S. Duboit), pp. 397-420. Springer, Berlin, Heidelberg, New York.

Soltis P.S. \& Soltis D.E. (2009) The role of hybridization in plant speciation. Annual Review of Plant Biology 60, 561-588.

Stupar R.M., Bhaskar P.B., Yandell B.S., et al. (2007) Phenotypic and transcriptomic changes associated with potato autopolyploidization. Genetics $\mathbf{1 7 6}$ 2055-2067.

Syvertsen J.P., Lee L.S. \& Grosser J.W. (2000) Limitations on growth and net gas exchange of diploid and tetraploid citrus rootstock cultivars grown at elevated $\mathrm{CO}_{2}$. Journal of the American Society for Horticultural Science $\mathbf{1 2 5}$, 228-234.

Tardieu F. \& Davies W.J. (1992) Stomatal response to abscisic acid is a function of current plant water status. Plant Physiology 98, 540-545.

Verslues P.E., Agarwal M., Katiyar-Agarwal S., Zhu J. \& Zhu J.K. (2006) Methods and concepts in quantifying resistance to drought, salt and freezing, abiotic stresses that affect plant water status. The Plant Journal 45, 523-539.

Xiong L., Ishitani M., Lee H. \& Zhu J.K. (2001) The Arabidopsis LOS5/ABA3 locus encodes a molybdenum cofactor sulfurase and modulates cold stressand osmotic stress-responsive gene expression. The Plant Cell 13, 2063 2083.

Xiong Y.C., Li F.M. \& Zhang T. (2006) Performance of wheat crops with different chromosome ploidy: root-sourced signals, drought tolerance, and yield performance. Planta 224, 710-718.

Yu Z., Haberer G., Matthes M., Rattei T., Mayer K.F., Gierl A. \& Torres-Ruiz R.A. (2010) Impact of natural genetic variation on the transcriptome of autotetraploid Arabidopsis thaliana. Proceedings of the National Academy of Sciences of the United States of America 107, 17809-17814.
Received 6 June 2012; received in revised form 13 September 2012; accepted for publication 17 September 2012

\section{SUPPORTING INFORMATION}

Additional Supporting Information may be found in the online version of this article:

Figure S1. Gene expression patterns in leaves of V/2xRL and V/4xRL.

Figure S2. Correlation between microarray and qRT-PCR expression analyses.

Table S1. Genes differentially expressed in the diploid (V/2xRL) genotype in response to water deficit.

Table S2. Genes differentially expressed in the autotetraploid (V/4xRL) genotype in response to water deficit.

Table S3. Significantly enriched functional categories in the group of genes induced by water deficit.

Table S4. Significantly enriched functional categories in the group of genes repressed by water deficit in V/2xRL and $\mathrm{V} / 4 \mathrm{xRL}$ trees.

Table S5. Relative abundance of induced genes in different functional categories. 


\begin{tabular}{|l|l|}
\hline \multicolumn{2}{|c|}{ Toppan Best-set Premedia Limited } \\
\hline Journal Code: PCE & Proofreader: Jason \\
\hline Article No: 12021 & Delivery date: 22 October 2012 \\
\hline Page Extent: 13 & Copyeditor: Mariel \\
\hline
\end{tabular}

\section{AUTHOR QUERY FORM}

Dear Author,

During the preparation of your manuscript for publication, the questions listed below have arisen. Please attend to these matters and return this form with your proof.

Many thanks for your assistance.

\begin{tabular}{|c|c|c|}
\hline $\begin{array}{l}\text { Query } \\
\text { References }\end{array}$ & Query & Remark \\
\hline q1 & $\begin{array}{l}\text { AUTHOR: Please check that all genes were set to italic, and proteins and enzymes } \\
\text { set to roman throughout the article, as per journal style. }\end{array}$ & \\
\hline q2 & $\begin{array}{l}\text { AUTHOR: As per journal style, the key-words list should not include words found } \\
\text { in the article title, thus two of the key words were deleted. Please confirm if this is } \\
\text { OK. }\end{array}$ & \\
\hline q3 & $\begin{array}{l}\text { AUTHOR: Soltis } 2009 \text { has been changed to Soltis \& Soltis } 2009 \text { so that this } \\
\text { citation matches the Reference List. Please confirm that this is correct. }\end{array}$ & \\
\hline $\mathrm{q} 4$ & $\begin{array}{l}\text { AUTHOR: Ramsay (2011) has been changed to Ramsey (2011) so that this citation } \\
\text { matches the Reference List. Please confirm that this is correct. }\end{array}$ & \\
\hline q5 & $\begin{array}{l}\text { AUTHOR: The word "inches" has been removed in the sentence, "T-budding was } \\
\text { performed. . ground." Please confirm that this is correct. }\end{array}$ & \\
\hline q6 & $\begin{array}{l}\text { AUTHOR: Barr and Weatherley (1962) has been changed to Barr and Weatherly } \\
\text { (1962) so that this citation matches the Reference List. Please confirm that this is } \\
\text { correct. }\end{array}$ & \\
\hline q7 & $\begin{array}{l}\text { AUTHOR: Please confirm that the correct product details have been inserted } \\
\text { throughout the article. If possible, please replace all bullet symbols with the } \\
\text { corresponding product details, e.g. company name, town or city, state (if USA) and } \\
\text { country. }\end{array}$ & \\
\hline q8 & $\begin{array}{l}\text { AUTHOR: Percival (2005) has not been included in the Reference List, please } \\
\text { supply full publication details. }\end{array}$ & \\
\hline q9 & $\begin{array}{l}\text { AUTHOR: Brumos et al. (2009) throughout the article has been changed to } \\
\text { Brumós et al. (2009) so that this citation matches the Reference List. Please } \\
\text { confirm that this is correct. }\end{array}$ & \\
\hline q10 & $\begin{array}{l}\text { AUTHOR: Smyth and Speed (2003) has not been included in the Reference List, } \\
\text { please supply full publication details. }\end{array}$ & \\
\hline q11 & $\begin{array}{l}\text { AUTHOR: Please check all website addresses and confirm that they are correct. } \\
\text { (Please note that it is the responsibility of the author(s) to ensure that all URLs } \\
\text { given in this article are correct and useable.) }\end{array}$ & \\
\hline q12 & $\begin{array}{l}\text { AUTHOR: The word "proceeded" has been deleted from the sentence, "Data } \\
\text { normalization and. . needed." Please confirm that this is correct. }\end{array}$ & \\
\hline q13 & $\begin{array}{l}\text { AUTHOR: "detoxification" and "detoxication" are both used in the text and in the } \\
\text { figures. Please confirm if this is OK. }\end{array}$ & \\
\hline q14 & $\begin{array}{l}\text { AUTHOR: Sahi et al. } 2003 \text { has not been included in the Reference List, please } \\
\text { supply full publication details. }\end{array}$ & \\
\hline
\end{tabular}




\begin{tabular}{|l|l|l|}
\hline q15 & $\begin{array}{l}\text { AUTHOR: Sahi, Singh, Blumwald, Grover, 2006 has not been cited in the text. } \\
\text { Please indicate where it should be cited; or delete from the Reference List. }\end{array}$ & \\
\hline q16 & $\begin{array}{l}\text { AUTHOR: Please confirm that the use of prime symbols is correct in Figure 1 } \\
\text { legend. }\end{array}$ & \\
\hline q17 & AUTHOR: Please confirm that Table 1 legend and footnote have been set correctly. & \\
\hline q18 & $\begin{array}{l}\text { AUTHOR: Please confirm that the use of prime symbols is correct in Table 1 } \\
\text { heading. }\end{array}$ & \\
\hline
\end{tabular}




\section{Please correct and return this set}

Please use the proof correction marks shown below for all alterations and corrections. If you wish to return your proof by fax you should ensure that all amendments are written clearly in dark ink and are made well within the page margins.

\begin{tabular}{|c|c|c|}
\hline Instruction to printer & Textual mark & Marginal mark \\
\hline Leave unchanged & ... under matter to remain & ( ) \\
\hline $\begin{array}{l}\text { Insert in text the matter } \\
\text { indicated in the margin }\end{array}$ & $h$ & $\begin{array}{l}\text { New matter followed by } \\
h \text { or } h \otimes\end{array}$ \\
\hline Delete & $\begin{array}{l}\text { I through single character, rule or underline } \\
\text { or }\end{array}$ & $\sigma$ or $\sigma(x)$ \\
\hline $\begin{array}{l}\text { Substitute character or } \\
\text { substitute part of one or } \\
\text { more word(s) }\end{array}$ & I through letter or & $\begin{array}{l}\text { new character / or } \\
\text { new characters / }\end{array}$ \\
\hline Change to italics & — under matter to be changed & $\leftarrow$ \\
\hline Change to capitals & $\equiv$ under matter to be changed & $\equiv$ \\
\hline Change to small capitals & $=$ under matter to be changed & $=$ \\
\hline Change to bold type & $\sim$ under matter to be changed & $\sim$ \\
\hline Change to bold italic & $\bar{\sim}$ under matter to be changed & $\tilde{\omega}$ \\
\hline Change to lower case & Encircle matter to be changed & $\Rightarrow$ \\
\hline Change italic to upright type & (As above) & \\
\hline Change bold to non-bold type & (As above) & \\
\hline Insert 'superior' character & $\begin{array}{l}/ \text { through character or } \\
K \text { where required }\end{array}$ & $\begin{array}{l}y^{\prime} \text { or } y \\
\text { under character } \\
\text { e.g. } y^{2} \text { or } y^{2}\end{array}$ \\
\hline Insert 'inferior' character & (As above) & $\begin{array}{l}\lambda \\
\text { over character } \\
\text { e.g. } \hat{\Sigma}\end{array}$ \\
\hline Insert full stop & (As above) & $\odot$ \\
\hline Insert comma & (As above) & , \\
\hline Insert single quotation marks & (As above) & $\begin{array}{l}\dot{y} \text { or } \dot{x} \text { and/or } \\
\dot{y} \text { or } \dot{y}\end{array}$ \\
\hline Insert double quotation marks & (As above) & $\begin{array}{l}\ddot{y} \text { or } \ddot{x} \text { and/or } \\
\ddot{y} \text { or } \ddot{x}\end{array}$ \\
\hline Insert hyphen & (As above) & 1 \\
\hline Start new paragraph & 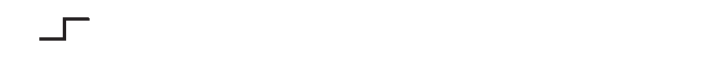 & 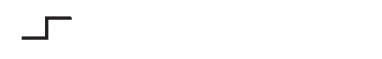 \\
\hline No new paragraph & $\infty$ & $\omega$ \\
\hline Transpose & $\sqcup$ & $\sqcup$ \\
\hline Close up & linking $\bigcirc$ characters & \\
\hline $\begin{array}{l}\text { Insert or substitute space } \\
\text { between characters or words }\end{array}$ & $\begin{array}{l}\text { I through character or } \\
K \text { where required }\end{array}$ & \\
\hline $\begin{array}{l}\text { Reduce space between } \\
\text { characters or words }\end{array}$ & $\begin{array}{l}\text { between characters or } \\
\text { words affected }\end{array}$ & $\uparrow$ \\
\hline
\end{tabular}

